Portland State University

PDXScholar

10-23-1996

\title{
La Relevancia de la Competencia Lexico-cultural del Lector en La Casa de los Espiritus: Desde un Acercamiento Hermeneutico
}

Gregory D. Lagos-Montoya

Portland State University

Follow this and additional works at: https://pdxscholar.library.pdx.edu/open_access_etds

Part of the Spanish and Portuguese Language and Literature Commons Let us know how access to this document benefits you.

\section{Recommended Citation}

Lagos-Montoya, Gregory D., "La Relevancia de la Competencia Lexico-cultural del Lector en La Casa de los Espiritus: Desde un Acercamiento Hermeneutico" (1996). Dissertations and Theses. Paper 5260. https://doi.org/10.15760/etd.7133

This Thesis is brought to you for free and open access. It has been accepted for inclusion in Dissertations and Theses by an authorized administrator of PDXScholar. Please contact us if we can make this document more accessible: pdxscholar@pdx.edu. 


\section{THESIS APPROVAL}

The abstract and thesis of Gregory D. Lagos-Montoya for the Master of Arts in Spanish were presented October 23, 1996, and accepted by the thesis committee and the department.

COMMITTEE APPROVALS:

DEPARTMENT APPROVAL:

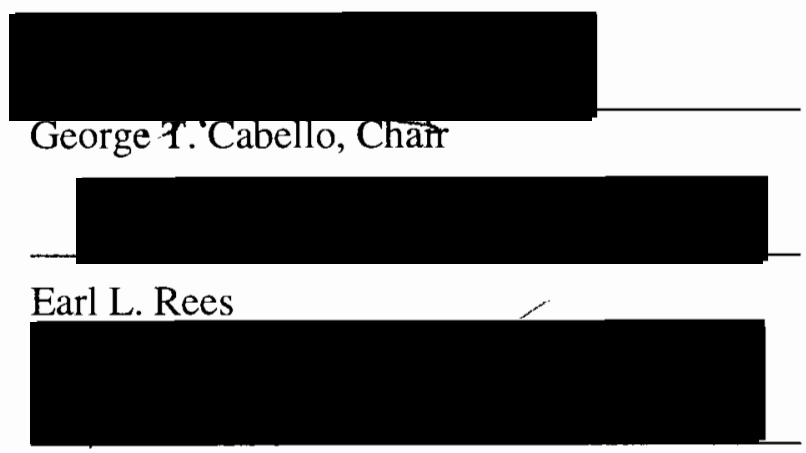

María Wilson-Figueroa

Representative of the Office of Graduate Studies

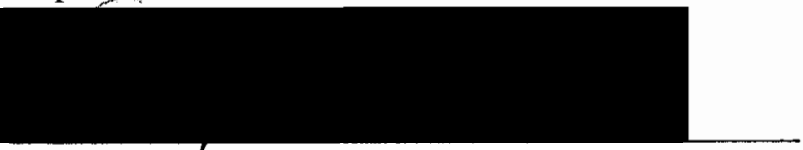

Louis J. Epteto, Chair

Department of Foreign Languages \& Literatures

$* * * * * * * * * * * * * * * * * * * * * * * * * * * * * * * * * * * * * * * * * * * * * * * * * * * * * * * * * * * * * * * * * * * *$

\section{ACCEPTED FOR PORTLAND STATE UNIVERSITY BY THE LIBRARY}

by

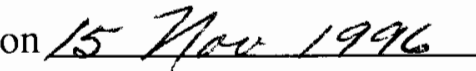




\begin{abstract}
O
An abstract of the thesis of Gregory D. Lagos-Montoya for the Master of Arts in Spanish presented October 23, 1996.
\end{abstract}

Título: La relevancia de la competencia léxico-cultural del lector en La casa de los espíritus: desde un acercamiento hermenéutico.

La competencia léxico-cultural del lector constituirá los cimientos para que éste perciba o no la fuente de inspiración de Isabel Allende en La casa de los espíritus. No cabe duda que ciertos lectores coincidirán con el aseveramiento de la propia autora: "que se ha basado su obra en Chile." Es un hecho que esta obra comprende una variedad de manifestaciones alusivas a este país: dialectológicas, socio-políticas, e históricas. Este estudio prueba que la competencia léxico-cultural de lector es vital para una comprensión más fiel de la obra.

La esencia de la obra literaria se manifiesta y complementa por medio de y gracias a la imaginación y asimilación de cada lector en particular; por ello, la validez interpretativa en La casa de los espíritus dependerá del flujo participativo que la lectura individual presente. Por lo tanto, no se podría afirmar que el lector no conocedor ni familiarizado con la vida socio-política de Chile y que interprete simplemente la obra como una sucesión de acontecimientos matizados con las diversas vivencias y facetas de una familia y un país —que supuestamente pudiesen situarse en cualquier punto de la América Meridional-, esté equivocado sino que, por el contrario, merece crédito de manera integral, ya que la obra alcanza su apogeo cuando logra que el lector se haga partícipe e integrante de ella de manera subconsciente y sutil. Así, se podría afirmar que 
la obra yace llana y dormitativa sin el suministro vital que le proporciona el lector. Empero, si no se lograra vislumbrar ciertas nociones hermenéuticas, el lector no podrá percibir la intención original que tenía la autora al momento de escribir su obra. La hermenéutica nos brinda el acercamiento integral entre autora y lector: en donde se envía un estímulo y éste se hace recíproco debido a que existe un mismo nivel o similar grado de entendimiento y/o competencia literaria/cultural. 


\section{LA RELEVANCIA DE LA COMPETENCIA LEXICO-CULTURAL DEL LECTOR EN LA CASA DE LOS ESPIRITUS: DESDE UN ACERCAMIENTO HERMENEUTICO}

by

GREGORY D. LAGOS-MONTOYA

A thesis submitted in partial fulfillment of the requirements for the degree of

MASTER OF ARTS

in

SPANISH

Portland State University 1996 


\section{INDICE}

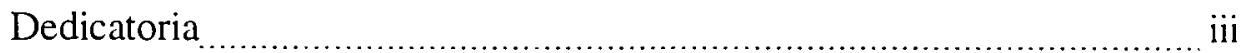

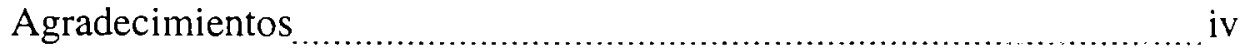

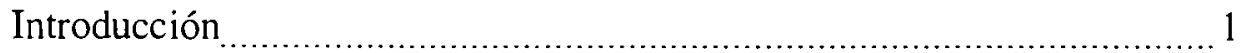

Relevancia de la competencia léxico-cultural en la obra ......................6

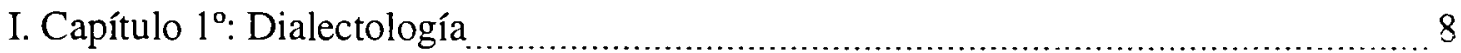

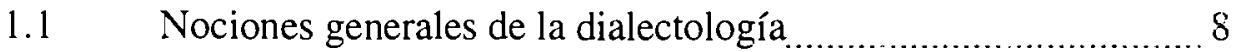

$1.2 \quad$ Aspectos dialectológicos en La casa de los espíritus .............. 10

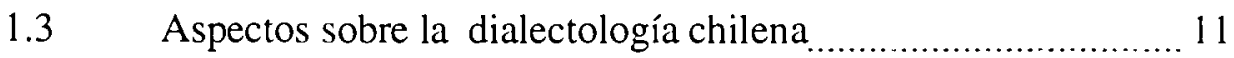

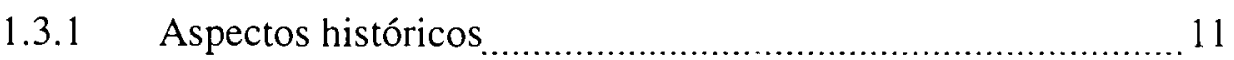

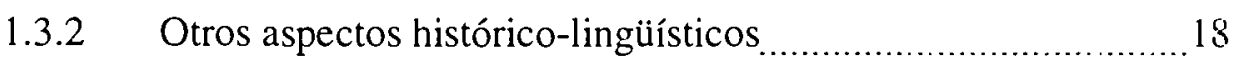

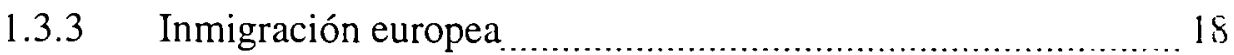

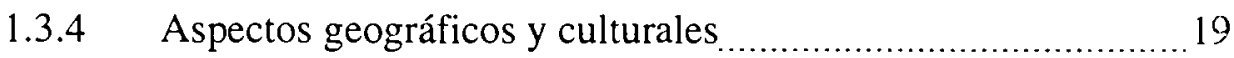

1.3.5 Distinciones léxicas del habla chilena ...........................20

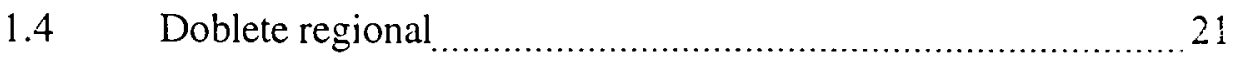

1.4.1 Dobletes en La casa de los espíritus ..............................22

1.4.2 Voces de uso peculiar y común en Chile ........................... 23

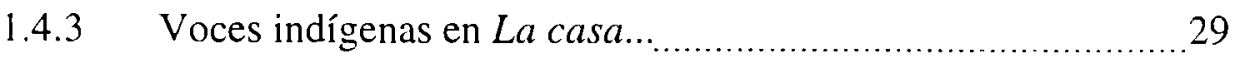

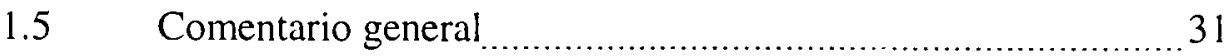

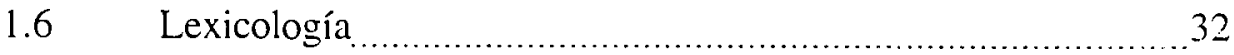

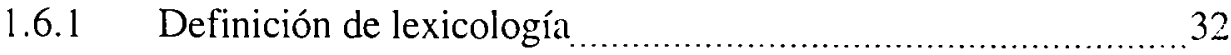

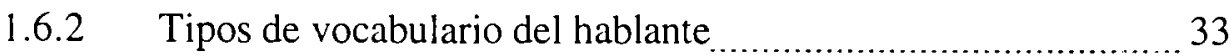

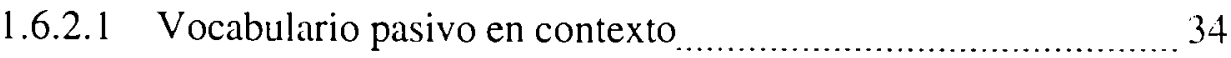

1.6.2.2 Nociones globales de vocabulario activo en la obra ............. 34 
1.6.2.3 Vocabulario pasivo en la obra

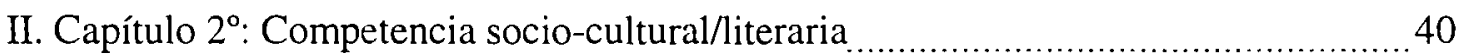

$2.1 \quad$ Aspectos generales ............................................................... 40

2.2 Evidencia textual desde una perspectiva interpretativa _............ 40

2.3 Pasajes de la obra y ambiente general ................................... 43

2.3.1 Citas ejemplificadoras ……................................................. 44

$2.4 \quad$ Técnica Roman à clef .......................................................... 54

2.4.1 Definición de Roman à clef................................................... 54

2.4.2 Personajes ficticios como reales ………................................. 55

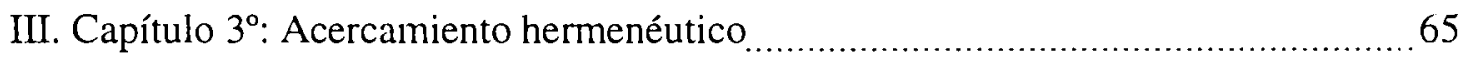

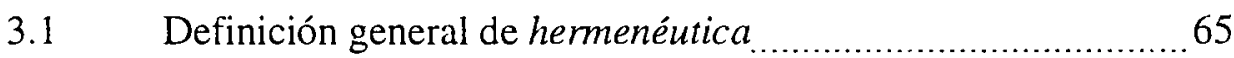

3.2 Perspectiva hermenéutica en La casa de los espiritus ...............66

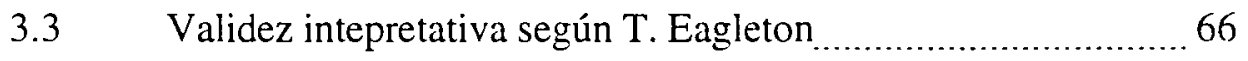

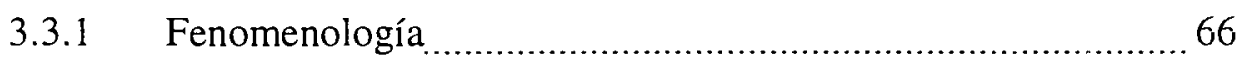

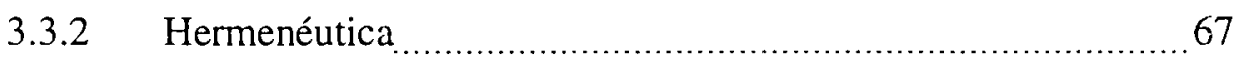

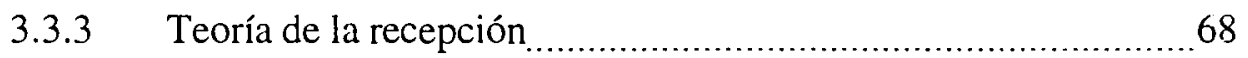

3.4 Aplicación hermenéutica en La casa de los espíritus ................69

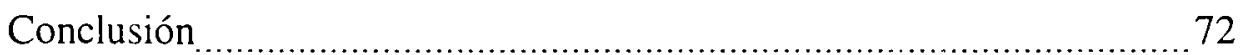

Notas

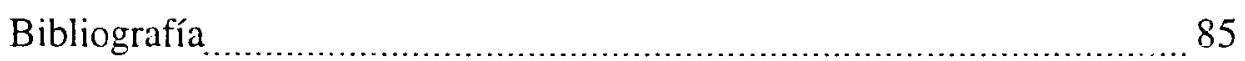

Anexos: 
Dedico esta tesis de grado a aquellas mujeres que han representado grandes pilares en $\mathrm{mi}$ vida:

De la Flia. Lagos: Ida, Marlene, Ximena, Mireya, Ingrid, Erika Maza de Valenzuela, Elianita Durán de Lagos, y Luisa Montoya; y aquellas mujeres que nunca olvidaré por su bondad: Prof. Margarita Melis, Margot Flansberg, Ellen Chase, Doris Bellingham, y Nancy Frugone-Ruz; y, finalmente, a mis inolvidables profesoras: Mila Hidalgo, y Marcia Lagos.

Isabel, tu casa se ha convertido para mí en un laberinto esclarecedor de un pasado tan intrigante como lamentable. A través de tus elocuentes hilvanaciones, he podido degustar y adentrarme en nuestro país y su gente, también desde la distancia. 


\section{A G R A D E C I M I N T OS}

Sin la grata acogida de mi tutor académico e integrantes del Comité de posgrado, y la valiosa cooperación de mis asesores en Chile, al igual que la de mis informantes en el extranjero, como aquellos que residen en Oregón, EE.UU., el presente trabajo no hubiese podido cumplir su objetivo. Hago extensivas mis infinitas y sinceras gracias a cada uno de ellos.

Alfonso Lloveras, Lic. en Letras

Alfredo Torrejón, Ph.D. en Linguística

Ana Franco, Contadora

Brian Hunter, estudiante universitario

Dr. Julio Guíñez, Ciruj., U. de la Frontera

Dr. Julio Maldonado, Médico

Edgardo Gübelín., Lic. en Historia

Eduardo González-Viaña, M.A. (WOSC)

Eduardo Labarca, Escritor, U. de Chile

Ellen Chase

Emily Polanshek-Glick, M.A.

Ingrid Lagos-Beckar, Pedagoga

Irene Aracena, U. del Biobío

Irene de Rector

J. Samuel Valenzuela, Ph.D. en Sociología

Julio Arroyo, estudiante universitario

Karin Rengifo, estudiante universitaria

Marcos Valencia, estudiante universitario

Marlene E. A. Lagos M., Secretaria

Mónica Salgado, B.A. Willamette Univ.

Montserrat Gimeno, Lic.

Nancy Frugone Ruz, ex-profesora

Olga Walmisley-Santiago, Ph.D. en Español

Scott Sadowsky, U. de Maryland

Sergio Yáñez, Secret. Munic., U. Concepción

Ximena Lagos M., Secretaria Admin.
Informante de Chile (Sta. Bárbara)

Colaborador en Auburn Univ., EE.UU.

Informante argentina en Salem, Oregón

Colaborador (EE.UU.)

Informante de Temuco, Chile

Informante de Honduras

Colaborador (U. de Concepción, Chile)

Informante de Perú

Colaborador en Viena, Austria

Colaboradora (EE.UU.)

Informante de EE.UU.

Colaboradora (Ch ile)

Informante de Sta. Bárbara, Chile

Informante argentina en Salem, Oregón

Colaborador en Notre Dame U., EE.UU.

Informante de México (D.F.)

Informante de Perú (Lima)

Informante de México (Veracruz)

Colaboradora (Sta. Bárbara, Chile)

Informante filipina en Salem, Oregón

Informante de España (Barcelona)

Colaboradora (Santiago de Chile)

Informante angloespañola en Oregón.

Colaborador, Maryland, EE.UU.

Informante de Santa Bárbara, Chile

Colaboradora en Santa Bárbara, Chile 


\section{INTRODUCCION}

Isabel Allende ha transcendido en el tiempo con sus aclamadas obras tales como: La casa de los espíritus, De amor y sombra, Eva Luna y Paula. Su estilo narrativo ha cautivado a lectores en diversas latitudes e idiomas con un sabor peculiar. Dichos elementos se caracterizan por ser simples, directos y -a la vez- floridos de matices que transportan fácilmente al lector a un espacio y tiempo por ser determinados por el lector - dentro de los márgenes y cánones de la narrativa. Cabe señalar que la popularidad de sus obras, está ligada a ciertos factores primordiales:

El estilo literario de Isabel Allende sobresale por su elocuencia, simpleza, exposición diáfana y transparente, e inclusive la visión de la vida de los personajes se transmite tan palpablemente que hace al lector fácil y fluidamente percibir y asimilar aquel vaivén de emociones que, generalmente, dormitan en la intimidad; y el parentezco de Isabel Allende (sobrina) con el primer presidente socialista-marxista -elegido democráticamente, Salvador Allende Gossens-, le da a la autora un reconocimiento casi instantáneo. Además, se debe mencionar el trágico final del Presidente Allende cuyo impacto se advierte tanto implícita como explícitamente en La casa... Y, finalmente, como periodista, Isabel Allende tuvo la ventaja de estar compenetrada de la realidad nacional para posteriormente poder denunciar fehacienmente los abusos de la Junta. 
Mi objetivo es explorar y exponer los elementos lexicológicos y ambientales que hacen esta obra de Allende una expresión testimonial de la sociedad chilena con su respectivo código lingüístico (i.e., uso primeramente de chilenismos y consecuentemente de americanismos pertinentes a este país). Y, de esa manera, descarto cualquier intención relacionada con el comprobar o indagar de qué manera la novelística de Allende encaja en el movimiento literario del realismo mágico, o el determinar el nivel de similitudes estilísticas que pudiese existir entre La casa... y Cien años de soledad de Gabriel García Márquez. Mi objetivo finalmente ha de ser el profundizar y adentrarme en aspectos hermenéuticos (o interpretativos), que proporcionen un aferramiento categórico al establecimiento temático e hipotético, con su variante castellana, pasado y rasgos idiosincráticos del pueblo chileno para así analizar y determinar hasta qué grado la competencia léxico-cultural del lector (o informantes de habla hispana, provenientes de diversas naciones) pudiese provocar una variación considerable en la recepción y calidad del mensaje e interpretación percibidos por los informantes $^{1}$ (ya familiarizados con la obra en estudio). El contenido de este trabajo comprenderá los siguientes temas centrales:

- Dialectología: Esto comprende un léxico, el cual he seleccionado minuciosamente - a pesar que no podría afirmar que no he pasado por alto más de algún término relevante- en este estudio hipotético. Dicho léxico presentará su respectiva etimología y uso idiomático correspondiente a la comunidad lingüística 
chilena. El propósito de este léxico —con sus respectivas denotaciones y connotaciones correspondientes - será el examinar la cantidad e inherente calidad de aquellos términos que pudiesen representar para ciertos lectores un obstáculo o para otros, una vía expedita en la comprensión y asimilación de aquellos vocablos que difieren connotativa y/o semánticamente dentro de las comunidades lingüísticas de la lengua española. Así entonces, este aspecto descriptivo tiene el fin de analizar la incidencia e implicancia que quizás tenga el hecho de poder identificar y reconocer aquellos elementos idiosincráticos y costumbristas presentes en la obra, los cuales son propios de un punto geográfico dado como lo es la nación chilena.

- Competencia socio-cultural/iteraria: Esto se refiere a la identificación y reconstrucción hipotéticas del medio geo-físico y hechos históricos de la obra, lo que implica pasajes y citas tomados de La casa.. ; dichos pasajes nítidamente hacen mención al orden geo-político de Chile. Y, por otra parte, esta sección presentará la aplicación y desarrollo de la técnica de la novela en clave o Roman à clef con respecto a La casa..; todo lo cual incluye la identificación de personajes supuestamente ficticios como personalidades reales y de relevancia en el acontecer político-histórico chileno.

- Acercamiento hermenéutico: La proyección significativa que se logra por medio de la fusión de la forma y el contenido de la obra, se relaciona cohesivamente a su subsecuente interpretación, para así visualizar la obra —de Allende en este caso— de acuerdo al mensaje e intención originales de la autora. Estas nociones interpretativas 
serán abarcadas según las premisas que exponen Hans-Georg Gadamer, primordialmente, y Terry Eagleton-éste como referencia general del estudio interpretativo contemporáneo de la obra literaria.

Por lo tanto, la presente hipótesis expone que el informante no conocedor ni familiarizado con cierta terminología y factores geo-políticos, presentes en La casa..., asimilará la obra, en general, como una mera narrativa: un enlazamiento de sucesos con un espacio y tiempo proclives a ser ficticios o relativos a cualquier zona latinoamericana. En su defecto, el informante conocedor ${ }^{2}$ de la historia y costumbres del país de origen de Isabel Allende, envisionará una manifestación socio-lingüística de Chile, con una gama pletórica de sutilezas y matices ilustrativos a las costumbres y hechos históricos de tal nación.

El propósito principal de esta investigación se basa en la percepción personal de una ilustración fidedigna del ambiente socio-cultural chileno que se encuentra impreso en la obra de Isabel Allende, mientras que para el resto de los integrantes del aula de clases —en una de nuestras cátedras literarias—, La casa... representaba únicamente una configuración de elementos ficticios que implicaban ciertos elementos espaciales y temporales, con patrones inspirados probablemente en la obra de García Márquez, y que cumplía con ciertos "requisitos" para ser catalogada como una obra mágico-realista... No obstante, para el autor de este trabajo, la obra de Allende englobaba más que un golpe de estado, un presidente socialista-marxista cuya presidencia había concluido en 
forma dramática. ${ }^{3}$ Por el contrario, La casa... fue y es para quién subscribe un reflejo de la cultura e historia de la nación chilena, con un abanico de evidencia esclarecedora de aquella nación remota, también llamada Finis Terrae . 


\section{LA RELEVANCIA DE LA COMPETENCIA LEXICO-CULTURAL DEL}

LECTOR EN LA CASA DE LOS ESPIRITUS: desde una perspectiva hermenéutica.

La casa de los espíritus ${ }^{4}$ engloba la inquietud de su autora, Isabel Allende, por expresar un pasado y una vida que en sí fueron interrumpidos y desmembrados por acontecimientos e intereses socio-económicos de sectores financieros y militares mayores. Isabel Allende señala que su obra ha sido el receptáculo de sus amarguras, tristezas y penurias, las cuales —aparentemente - aunque se alivien por medio de la expresión escrita, es sólo en forma momentánea, ya que su padecer y zozobra son perennes. Precisamente, Isabel Allende indica categóricamente que su obra ha sido inspirada en las peculiaridades, encantos, narraciones amenas de su familia, y congoja y sufrimientos de aquel pueblo que fue testigo de atrocidades jamás experimentadas (Allende. Is There Such A Thing as Latin American Literature?) ${ }^{5}$.

El propósito de esta tesis es demarcar la situación dialectal, ambiental y descriptiva de Chile que se manifiesta en La casa... Con dicho objetivo, el aporte general de los informantes, integrará una parte esencial en la composición y desarrollo de esta tesis de grado. En síntesis, ellos serán de suma relevancia ya sea para ratificar, o — en su defecto—- refutar el postulado de mi hipótesis, el cual consiste en lo siguiente:

La competencia" léxico-cultural del lector en La casa... puede representar una vía expedita para unos, y un obstáculo nebuloso para otros, dependiendo del trasfondo que 
se tenga sobre la historia y sociedad chilenas. El lector deberá percibir las sutilezas y matices descriptivos inherentes a la obra, esto es, un abanico de rasgos geo-físicos, histórico-políticos, sociolingüísticos y costumbristas para llegar a una visión más fiel del mensaje e intención originales de Isabel Allende.

El corpus de la presente tesis se basa en el estudio de los aspectos lingüísticos que tienen el propósito de llegar a un entendimiento íntegro de la interpretación objetiva de La casa..., vale decir, la aplicación de tratados lingüístico-literarios conducentes, finalmente, a un acercamiento hermenéutico en dicha obra. 
Capítulo $1^{\circ}$ : Dialectología

\subsection{Nociones generales de dialectología}

La dialectología es la rama de la lingüística que trata el estudio del habla perteneciente a una comunidad lingüística (CL) dada, es decir, sus rasgos diferenciadores que de manera arraigada, permiten separar como así también distinguir el conjunto de características que define el habla de un pueblo como un ente idiosincrático y peculiar. Cada CL se desarrolla, proyecta y evoluciona de manera singular. En esta evolución son, por lo general, grupos prominentes de la sociedad los que desempeñan un papel fundamental, puesto que son ellos los que tácita, sutil y paulatinamente sirven de modelo lingüístico para el resto de la población; y así se trata intrínsicamente de unificar o estandarizar el habla (perteneciente a un nivel de educación apropiado) y sus normas prescriptivas como fenómenos descriptivos propios de cada comunidad y a la vez de cada isoglosa. (Cabe señalar que el habla norma es lo que se percibe, por lo común, en los medios de comunicación con cierto renombre de un país y aquel registro que se aprecia en discursos públicos formales)?

En términos etimológicos, debiera indicarse que dialectología proviene del vocablo griego compuesto: $\delta i \alpha$ (dia: por medio de), $\lambda \varepsilon \kappa \tau$ o $($ lektos= conversación), $\lambda o$ of $(\operatorname{logos}=$ palabra, lógica, estudio o tratado $)$, de lo cual se puede resumir que es el estudio del tipo y estilo del lenguaje empleado en cierta región o CL. Este tratado cobra 
realce, en forma notoria, cuando se aplica a los países de habla hispana en los que se puede apreciar la evolución y bifurcaciones del uso del idioma desde una perspectiva diacrónica como también sincrónica.

Las variantes de la lengua española —así como ocurre con la mayoría de las lenguas vivas- se deben a acontecimientos históricos y fenómenos sociolinguísticos tales como: influencia de dialectos o idiomas oriundos o indígenas (como es el caso de América Latina con el castellano ${ }^{8}$ y la influencia del náhuatl, quichua ${ }^{9}$, aimará, guaraní, mapudungún ${ }^{10}$, taíno y otros). También influyen el flujo inmigratorio, factores geoclimáticos, socio-económicos, educativos e idiosincráticos.

Todos los aspectos mencionados, ciertamente, han moldeado y proseguirán caracterizando el lenguaje y uso descriptivo de éste en un contexto determinado. Así también, se debe recalcar que cada CL determina y establece su propio registro norma (válido dentro de sus respectivas comunidades o isoglosas). Esto —de una manera $\mathrm{u}$ otra - implica que es una realidad que cada CL no se aferra ciegamente a lo que indique o determine la gramática prescriptiva — sin desmerecer de ninguna manera los atributos constructivos de ésta para mantener los cánones de la lengua como lo es la función del Diccionario de la Real Academia de la Lengua Española (DRAE).

La dialectología basa sus conceptos en el uso del lenguaje descriptivo, es decir, el análisis de la manera peculiar que habla (o con que se expresa) una CL, (esto es, una comunidad, una región, o incluso un país o isoglosa), incluyendo cualquier fenómeno 
lingüístico constituyente en el habla: asimilación, desimilación, truncamientos, variantes libres, elisión, sobregeneralizaciones en todos o cualquiera de sus aspectos (ya sean, fonéticos, semánticos, sintácticos o lexicológicos).

\subsection{Aspectos dialectológicos generales en La casa de los espíritus}

En esta sección, he prestado especial atención a la dicción (la selección de palabras) empleada en La casa... Los vocablos que utilizo para esta selección son aquéllos que se caracterizaron por ser modismos y/o expresiones idiomáticas presentes en la obra de Isabel Allende, los cuales son típicamente empleados a diario en Chile. La frecuencia de dichos términos es categórica y de uso común y corriente, esto es, vocablos fácilmente reconocidos por los miembros de la comunidad en cuestión, los que inclusive al ser listados en forma aislada (sin contexto) serían fácilmente reconocidos.

Para realizar un estudio dialectológico, se recomienda analizar los mismos vocablos (y su producción) en cuestión, en diversos modos: aislados, en contexto escrito y oral (Ducrot 58). Debido a que he considerado los vocablos correspondientes a esta sección como términos de uso común para la mayoría de los hablantes de la comunidad lingüística chilena, me he limitado a comprobar sólamente si mis informantes los pueden reconocer dentro de una polaridad mínima: positiva o negativa; de ser positiva, el informante expondrá una explicación concisa referente al término; y 
- por otra parte - he de corroborar con una definición alusiva de fuentes fidedignas (tales como: los léxicos de la RAE, Corominas, Academia Chilena de la Lengua, Morínigo, Sopena —entre otros).

\subsection{Aspectos sobre la dialectología chilena}

La dialectología chilena conforma una manifestación lingüística -compuesta por diversas fuentes léxicas - provenientes de la principal lengua romance hablada en la Península Ibérica, i.e., el castellano, complementada en casos específicos por ciertos giros provenientes del mozárabe, gallego, catalán, leonés, aragonés y además por otras fuentes que han contribuido al enriquecimiento de la lengua.

\subsubsection{Aspectos históricos}

Al referirse al campo de la dialectología, resulta crucial el mencionar ciertos aspectos históricos que — de una manera u otra — han esculpido la fisonomía del habla del país. Por ello, me remonto al descubrimiento y conquista de Chile.

Al arribo de Diego de Almagro ("descubridor" de Chile) al territorio - en 1535- que a posteriori se conocería como la Capitanía General de Chile bajo la jurisdicción del Virreinato del Perú, este remoto territorio presentaba una población étnica relativamente pequeña y a la vez dispersa. Los distintos pueblos indígenas esparcidos a lo largo del territorio, debido a su bajo contingente y su concomitante 
separación, nunca presentaron un poderío u oposición de mayor transcendencia. Entre estos pueblos, cabe señalar a los siguientes: (de norte a sur) atacameños, diaguitas. picunches, pehuenches, mapuches, huilliches; chonos, alacalufes y onas (fueguinos ${ }^{11}$ ). El legado lexicológico, sin embargo, corresponde y está ligado primordialmente a aquellos grupos nortinos — por una parte — que recibieron un gran aporte lingüístico y cultural de los incas; como también en casos específicos de reducidos grupos parlantes del aimará. Por otra parte, más al sur, fueron los mapuches, quienes además, fueron los únicos que al contactarse con los españoles también aprendieron tácticas para posteriormente atacar a los ibéricos invasores y así defender su patrimonio.

Los incas —antes de la conquista española — llegaron hasta la séptima región (o Región del Maule) del centro de Chile, difundiendo sus avances y técnicas agrícolas, conjuntamente con su lengua entre los pueblos indígenas de Chile. Por ello, —en la actualidad - se aprecia un número considerable de giros que presentan una etimología quichua y que han sido integralmente adaptados en el habla de Chile, así como en otras naciones de la América Meridional.

Tanto los incas como los españoles se enfrentaron con la fuerte oposición por parte del pueblo mapuche (o como se les denomina genéricamente en español, araucanos). La conquista de Chile fue más difícil para los españoles que en el resto de la América Latina; aun hasta el fin de la colonia, los mapuches ofrecieron una resistencia 
formidable a las tropas españolas. La Guerra de Arauco produjo un influjo constante de españoles, hasta el periodo de la Independencia (1810-1818).

Nótese que este prolongado enfrentamiento en Chile resulta interesante en el sentido de que el castellano transplantado de España se fue modificando con el influjo constante y paulatino de nuevos soldados y colonos a la Capitanía General de Chile (que no necesaria ni exclusivamente provenían de la región Extremadura-Andalucía), lo que se contrasta notoriamente con el castellano más estable perteneciente al Virreinato del Perú y el de Nueva España, que no tardó demasiado en cobrar un cierto señorío en dichas cortes reales (Moreno 59-73).

El patrimonio cultural como racial del pueblo mapuche ha sido un componente relevante en la sociedad chilena en diversos aspectos. Esta influencia es tan crucial en el desarrollo socio-lingüístico de Chile que llegó a confundir al destacado filólogo, Rodolfo Lenz, que se dedicó al estudio minucioso de la dialectología chilena, llegando a pensar que las peculiaridades del habla de este país eran fidedignas influencias e interferencias de la lengua del pueblo mapuche, mapudungún. Esta apresurada conclusión se debió a diversas distinciones encontradas en la producción del castellano hablado en Chile. (e.g.: produción alofónica del grupo consonántico -tr- que se articula con cierta elevación y preponderancia alveopalatal [especialmente en la zona central] en contraste al castellano norma en el cual este sonido tiene un punto de articulación dento-alveolar). Esta 
aseveración se desmintió fehacientemente por varios lingüistas que sucedieron a Lenz en el campo de la dialectología chilena.

La conclusión de Lenz (que fuera rectificada por Amado Alonso) alude a fenómenos de producción libre ( $\mathrm{y}$ —n casos- menos prescriptiva) que también se presentan en otras comunidades lingüísticas de América Latina, en especial, en aquellas pertenecientes al vernáculo de los estratos menos educados, así como en ciertas regiones de España. Esto indica que todos los fenómenos de libre producción, en general, fueron simplemente transplantados desde la Península a América. Por ejemplo:

a) La producción de sonido africado como fricativo, vale decir, $/ \mathrm{t} / \mathrm{l}=\mathrm{=} / \mathrm{J} / \mathrm{i}^{12}$

e.g.: chao /t $\int$ áo/ vs. / áo / coche /kótje/ vs. /kófe/

b) Aspiración de /s/ antes de consonante o en posición final y prolongación de la vocal que precede a 's'.

e.g.: el castellano /el kaHteyáno/ = aspiración antes de consonate el compaz /el kompáH/ = aspiración en posición final los papás /lo: papá:/ = prolongación vocálica

c) Disimilación u omisión de ciertos sonidos fricativos (generalmente, debido a factores correspondientes a relajamiento articulatorio o economía lingüística), tales como /b/y /d/ fricativas en posición intervocálica ${ }^{14}$ (característico del vernáculo andaluz, además). i.e.: 
cabeza /ka:ésal

dedo /dé:o/

d) Seísmo. El sonido interdental sordo correspondiente a /ç/ y / $\theta /$, nunca logró establecerse en el Nuevo Continente: simplificando el caso de las sibilantes en /s/ para todos los casos (naturalmente que con diferente intensificación sonora de acuerdo a cada región). e.g.:

$$
\text { caza } / \text { kása } /=\text { casa } / \text { kása/ }
$$

e) Yeísmo: el sonido /j/ rápidamente ha remplazado al fonema de $-11-0 / \lambda /^{15}$.

Salvo en casos exclusivos, se puede apreciar la producción de $/ \lambda /$ en ciertos hablantes de edad avanzada como aquéllos que residen en comunidades relativamente aisladas. (El yeísmo también ya se aprecia en España como norma).

$$
\begin{aligned}
& \text { e.g.: halla láyal } \\
& \text { haya láyal }
\end{aligned}
$$

La mayoría de estos fenómenos linguísticos también se aprecian en las regiones de Andalucía-Extremadura; no obstante, existen ciertos casos que se dan en otras áreas del Norte de España (como la pronunciación de -tr- en partes de la capital santiaguina que también se registra en ciertos hablantes del centro y norte de España). Esto contribuye al hecho que implica que el flujo de inmigrantes ibéricos no se limitó a Andalucía- 
Extremadura en América. Sin embargo, en el caso de Chile, Oroz Scheibe menciona lo siguiente en su obra, La lengua castellana en Chile :

El léxico actual de Chile muestra buen número de evidentes coincidencias con el de la región andaluza y en mucho mayor grado que con el vocabulario de Aragón o Salamanca... hemos recogido.... un $2,3 \%$ de voces como de uso corriente en Chile, con significado, en su mayor parte, completamente idéntico [a] andaluz], y en otros casos por lo menos muy similar. (23)

Por otra parte, Oroz señala:

Sabemos que América no fue poblada únicamente por aventureros y guerreros sin cultura, sino que entre los conquistadores y primeros colonos vinieron también representantes de la clase más culta de España, clérigos, hidalgos y aun algunos nobles. (25)

Es un hecho que un español (proveniente del centro o norte de España) podrá encontrar varias similitudes en la producción fonológica andulaza y la chilena así como también el castellano de la mayoría de las zonas bajas o costeñas de América Latina (Moreno 66). 
Así, el habla en Chile muestra orígenes en ultramar con sus respectivos cánones y valores léxicos; no obstante, cada lengua viva debe permanecer en una evolución constante y flexible para no perecer en la historia como lo experimentó el latín clásico. Es natural en un sistema comunicativo el adaptarse a nuevas situaciones, complementarse, $\mathrm{y}$-de hecho- emanciparse de normativas rígidas, ya que el lenguaje debe servir para incitar el intercambio de ideas e información de forma fluida y expedita.

Naturalmente, la incidencia de los vocablos pertenecientes al mapudungún sólo resultan de relevancia en la isoglosa de Chile (específicamente, en las zonas centrales y meridionales como australes -al igual que en las zonas centro-occidentales de Argentina ${ }^{16}$ ). El aporte de la lengua de los mapuches sólo ha cruzado las fronteras internacionales por medio de contadas voces; e.g.: "poncho", "coipo", "quillay" (Quillaya saponaria). El resto de los vocablos mapuches se usan —en la actualidadprincipalmente en Chile y Argentina de manera cotidiana; y éstos pertenecen a un registro socio-lingüístico más bien coloquial, o —en ciertos casos— vernacular.

Sin embargo, el filólogo español, Alonso Zamora (miembro de la Real Academia), ve y resume drástica y concisamente el legado indígena de la siguiente manera: Debe destacarse, [que] ...el sustrato léxico [indígena] se refleja especialemente sobre aspectos de la vida material, concreta, localizada sobre cosas y manifestaciones del vivir cotidiano. Para la vida del espíritu, el vehículo obligado [era y] es el español patrimonial (396). 
En síntesis, aparte de destacar el aspecto histórico, es decir, el mestizaje, la lengua española encontró una nomenclatura variada, que con el transcurso del tiempo, se incorporó a la lengua culta; por lo consiguiente, se explica la incorporación de diversos términos del mapudungún, lengua de los mapuches, a la lengua indoeuropea impuesta en Chile.

\subsubsection{Otros aspectos histórico-lingüísticos}

Las próximas páginas de este escrito abarcan nociones —a grandes rasgos- de la influencia lexicológica experimentada desde la época pos-colonial en adelante en Chile.

\subsubsection{Inmigración europea}

En relación al período poscolonial, se debe remarcar el hecho que Chile recibió un marcado flujo de inmigrantes proveniente del País Vasco que — de una forma u otra - contribuyeron a formar el carácter nacional de los chilenos con la apacibilidad existencial y en el típico esmero en su obrar. A esto se refiere Salvatore Bizzarro:

Two great influxes of Basque immigrants were registered in Chile, and so important have they been to the ethnic constitution of the nation that Basque Miguel de Unamuno claimed Chile [...] to be [one of] "the two creations of the Basque race". The first wave of Basque immigrants 
arrived in Chile in the 17 th and 18th centuries, when $45 \%$ of all immigrants were Basques... (55)

Así también, a mediados del siglo XIX, Chile principió a atraer una variedad de inmigrantes europeos (alemanes, ingleses, franceses, italianos y croatas). ${ }^{17}$ Dichos grupos se complementaron a causa de la Primera y Segunda Guerra Mundial con la adición de otros grupos menores de inmigrantes tales como judíos (de la Europa Oriental), libaneses cristianos, palestinos, sirios en adición a nuevos españoles e italianos del norte (Hudson 79).

\subsubsection{Aspectos geográficos y culturales}

Por otra parte, la situación geográfica de Chile -comparable a la de una isla ${ }^{18}$ dentro de Sudamérica - ha guíado al país por rumbos muy distintos que el resto de América Latina. Este aislamiento en conjunto a su sistema educativo ${ }^{19}$ posteriormente, tal vez, han influido en la estructuración de su dialecto y acento. Chile, en la actualidad, presenta "remanentes" de voces o arcaísmos ${ }^{20}$ — valga la redundancia — desde el siglo XVI (más precisamente, desde la época de la Colonia) que se consideran como vocablos obsoletos en la España de hoy; y lo que en menor grado sucede con las otras naciones latinoamericanas. 


\subsubsection{Distinciones léxicas del habla chilena}

El lingüista estadounidense, John Lipski, ha resumindo las siguientes voces como las más características del pueblo chileno que difieren notablemente en el resto del mundo hispano, ya sea en España como América Latina. (Lipski, Latin American Spanish: Chile 203) Nótese que las siguientes voces es sólo una selección del listado propuesto por Lipski.

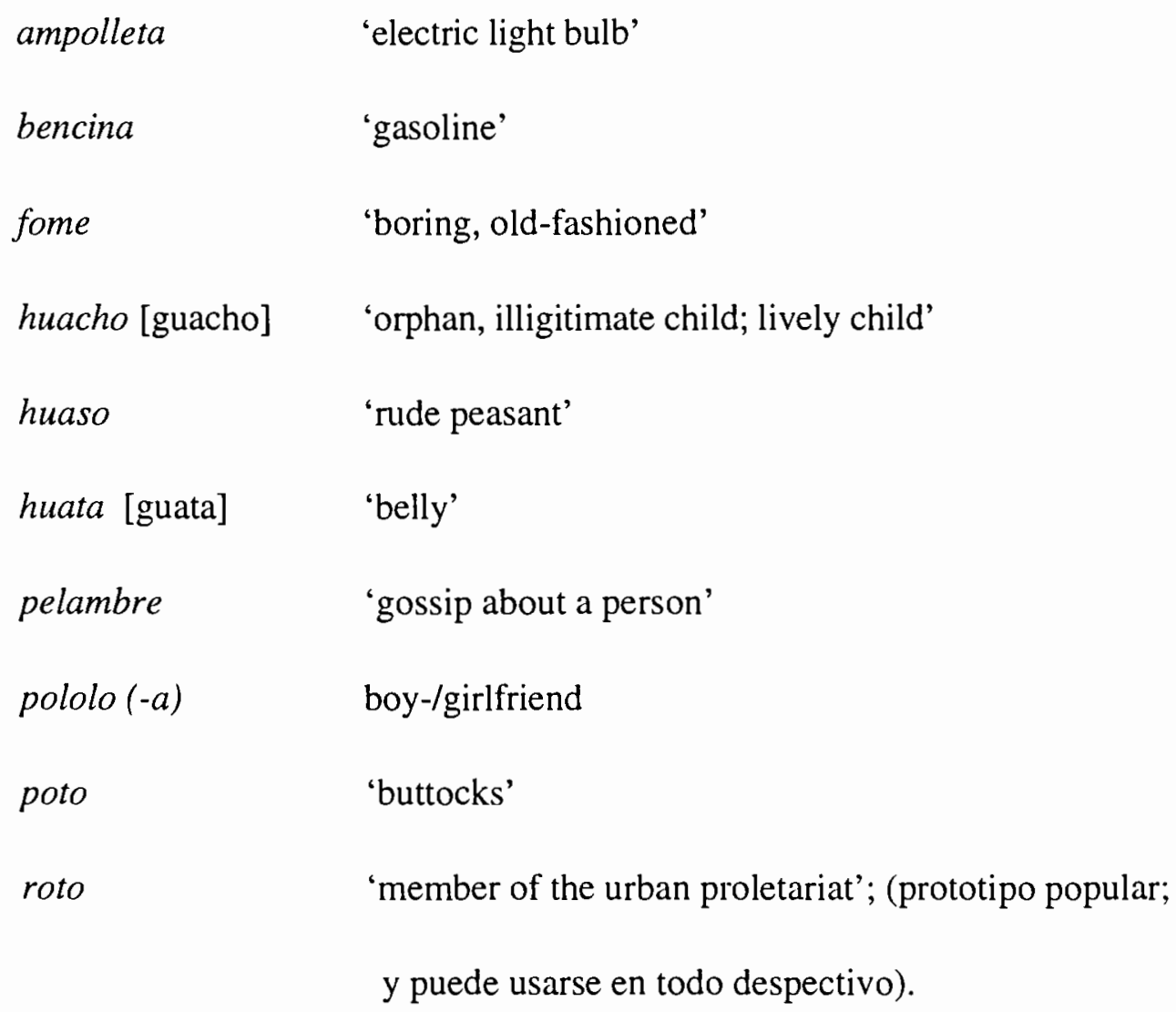

Aparte de la selección de Lipski, cabe señalar que tales expresiones como "tomar once" ${ }^{21}$ y "fundo" son representativas del habla cotidiana chilena, cuyos 
significados son "tomar el té" (de las 5 de la tarde como lo es el high tea inglés), y "hacienda", respectivamente.

\subsection{Doblete regional}

La evolución de la dicción cotidiana y las diferencias en la nomenclatura de los constituyentes del ambiente diario (vegetales, prendas de vestir, expresiones idiomáticas, etc.) ejemplifican, en casos, el fenómeno correspondiente al doblete regional. Esto se refiere al significado y significante de una entidad dada que son los mismos, pero el conjunto de grafemas por el cual se expresa es distinto en determinados puntos geográficos o comunidades linguiísticas. No obstante, no sólo razones históricas explican el concepto del "doblete regional" como ocurre al nombrar los nuevos aparatos y dispositivos de la alta tecnología, que en el caso de América Latina, generalmente, se ve influenciada por EE.UU. y, por el contrario, España lo era por Francia en ciertas instancias, debido - propiamente tal- al factor de la cercanía geográfica ${ }^{22}$. Una ilustración de este caso corresponde a la palabra: "computador-a" (ingl.: "computer") vs. la acepción peninsular: "ordenador" (fr.: "ordenateur"). P.H. de la Noix explica el concepto del "doblete regional" de la siguiente manera:

El doblete es otro ejemplo de diferencia diatópica [que es

la variable que provoca diferencias en la LENGUA, determinadas por causas geográficas]. Consiste en el 
empleo de dos o más palabras que tienen el mismo significado; pero el uso de cada una de ellas se restringe a una determinada región. Ej.: En Chile empleamos la palabra 'maní' y en Centro América y España se emplea la palabra 'cacahuete'. Ambas palabras forman un doblete; significan exactamente lo mismo. Pertenecen al léxico español oficial, pero cada una de ellas se emplea en una determinada zona geográfica, y no ambas simultáneamente en una misma región. (190)

1.4.1. Dobletes regionales en La casa de los espíritus

Con lo expuesto anteriormente, nos damos cuenta que la lengua española presenta un abanico riquísimo en términos de su diversidad lexicológica. En las próximas páginas, hago mención a la influencia que esta diversidad lexicológica pudiese ejercer en la recepción del lector en La casa..., por medio de ejemplos concretos (i.e., vocablos) tomados de la obra en sí.

Con las ejemplificaciones expuestas a continuación, se ratifica el hecho de que Isabel Allende no sólo describe el escenario socio-político de Chile, sino que también deja su respectivo código sociolingüístico como evidencia impresa. A excepción de los siguientes casos: "bombillo/a" que tiene una connotación diferente en Chile (i.e., paja 
[utilizada para succionar líquidos]; "chofer" también aparece como "chófer", siendo la acentuación grave más aceptada en España que la aguda de América Latina.

1.4.2 Voces de uso peculiar y común en Chile, presentes en La casa de los espíritus.

Nótese que los siguientes términos se han tomado de La casa... seguidos inmediatamente por su respectivo número de página(-s). A continuación y entre paréntesis, se indica las fuentes correspondientes.

Carabineros-194-5, 209, 258-9-(DRAE). Del italiano carabinieri. El 27 se abril de 1927 se estableció el Cuerpo de Carabineros de Chile, cuyo fundador fue el Presidente Carlos Ibáñez del Campo, quien se basara en el cuerpo policiaco de Mussulini (Alegría [versión inglesa] 29). El DRAE define "carabinero" como un soldado que usaba una carabina. El pretérito imperfecto utilizado en tal descripción deja de manifiesto que se refiere a un soldado del pasado; y debe señalarse que en la actualidad Chile es el único país - -de habla española— que denomina a su cuerpo policial como "carabineros" (cf. ilustración en Anexo).

Castellano-238, 325-(DRAE). "Nombre que alterna con el de español para designar esta lengua. Esta alternancia fue favorecida por la Real Academia Española, que hasta 1924 utilizó el nombre de castellano en su Diccionario y en su 
Gramática. Apartir de ese año, estas obras aluden ya a la 'lengua española', Menéndez Pidal escribió en 1928: «Este término induce erróneamente a creer, dado su valor geográfico restringido, que fuera de Castilla no se habla la lengua literaria sino como importación...» ...En Hispanoamérica, el problema vive: «Hay millones de hispanoamericanos que usan ambos nombres [castellano y español] indistintamente; pero, en general, se advierte preferencia -rara vez excluyente- por castellano..." (Fernando Lázaro 82-83)

Precisamente, en Chile se utiliza el nominal de castellano (difundido así por el sistema educacional, además), dejando connotativamente- el nombre de español para designar la variante peninsular de la lengua, por ej., con su típica producción notoria de los sibilantes, ceceo y el fricativo interdental sonoro de " $d$ ", etc.

Covadonga-119, 202-(SOPENA). "Aldea del Principado de Asturias. Cueva, valle y santuario célebres, porque allí derrotó Pelayo en 718 a un ejército moro y dio con ello comienzo a la Reconquista” [de España contra los árabes] II Y según Torechio: "Nombre de una goleta española que obtuvo Chile en el Combate de Papudo (26 de noviembre de 1865 ). Esta pequeña corbeta trasciende en la Historia de Chile, ya que Carlos Condell, a su mando, en el Combate Naval de Punta Gruesa hizo encallar al acorazado peruano 
Independencia; mientras la Esmeralda al mando de Arturo Prat sucumbía frente al blindado peruano Huáscar en la rada de Iquique (46, $128-9)$.

Así, es bien conocido para los chilenos que este buque se utilizó junto al buque la "Esmeralda"- para combatir contra la Confederación Peruano-boliviana en la Guerra del Pacífico (en el Combate Naval de Iquique, el 21 de mayo de 1879).

Cafiche (de cafisho)-115-(D.A. $S^{23}$ ). Lunfardo. Rufián, chulo, lacho ${ }^{24}$ que vive a expensas de su querida. Nótese que el uso corriente del vocablo "cafiche" en Chile, manifiesta la fácil difusión y adaptación que ciertos términos han tenido al cruzar la frontera andina, es decir, de la cuna del lunfardo, los barrios bajos -en un principio- de Buenos Aires a Chile, o de Atlántico a Pacífico.

Cuco-81, 245-(DRAE). Coco, del portugués côco. (Fantasma que lleva una calabaza vacía, a modo de cabeza.) Fantasma que se figura para meter miedo a los niños ("cuco" es la variante utilizada en Chile del vocablo "coco", siendo "coco" la ortografía que se emplea en la mayoría de los países de habla hispana).

Departamento-314, 328-(DRAE). Argent., Bol., Chile, Ecuad., Méj., Perú y Urug. Apartamento [o como se dice de manera coloquial en España, piso]. 
Diaguitas-207-(Larousse 1996). Pueblo amerindio ya extinguido que vivía en el NO de Argentina y Chile (entre los ríos Copiapó y Choapa). Se han descubierto poblados fortificados (pucará), así como objetos de cobre, oro y plata, y urnas funerarias de cerámica... Por otra parte, Torechio indica: "Su contacto con otras culturas agro-alfareras andinas los hizo evolucionar hacia manifestaciones artísticas como la cerámica y el fundido de cobre... Su cultura alcanzó el apogeo en el siglo XV. A fines de este siglo el territorio de los diaguitas fue sometido por los incas." (56)

Por ello, cuando se menciona en La casa... que el Conde de Satigny, después de desposar a Blanca, se dirigiría al Norte, donde pensaba vivir a expensas de su mujer; como también tenía planeado iniciar "un negocio de cántaros diaguitas y momias indígenas" (207); por lo tanto, resulta fácil remontarse al nuevo medio ambiente de la residencia de Jean de Satigny, vale decir, el árido norte de Chile. Compárese lo referente al cura alemán que estableció el museo de objetos de alfarería y momias indígenas (La casa... 245).

Fundo-54, 131, 170, 337-8-(DRAE). Latín, fundus. [En] derecho, heredad o finca rústica. El DRAE muestra este término como parte de una nomenclatura o jerga más bien jurídica o legal, mientras que el uso corriente de "fundo" en Chile es sinónimo de hacienda o como se dice en Argentina, estancias; o 
en Venezuela, fincas, etc. (El significado de "fundo" es probablemente un arcaísmo que ha prevalecido en Chile como el término más general para "hacienda" [término, probablemente, más empleado en los tiempos de los latifundistas]).

Guarisapo-60, 170-(DRAE). (Variante de gusarapo. ${ }^{25}$ ) Chile. Renacuajo, larva de la rana.

Mandas-21-(DRAE). De mandar. Andalucía y Chile. Voto o promesa hecha a Dios o a un santo.

Manta de Castilla-39-(DRAE). (de Castilla, de donde procedía esta tela). Chile. Bayetón, tela de lana con mucho pelo.

Por extensión, tenemos que manta se define, por lo general, como una prenda para abrigarse; y manta de Castilla se refiere a dicha manta cuya confección está compuesta de bayetón o algodón. En Chile, especialmente, en las zonas andinas y sureñas, las mantas de Castilla resultan muy útiles para los campesinos o "huasos chilenos" (más adinerados, por lo general), ya que éstas son un tipo de poncho de tela gruesa de algodón (de color negro), las cuales están diseñadas para soportar las bajas temperaturas como para repeler la lluvia; su precio es relativamente elevado, debido a su alta calidad y durabilidad. (comentario personal.) Véase, ilustración de un sureño chileno llevando una manta de Castilla típica, en Anexo. 
Mucama-237-(DRAE).Voz brasileña. Argent., Cuba, Chile, Par., y Urug. Criado, servidor. Argent., en hospitales y hoteles [en Chile, sólo en hoteles], persona encargada de la limpieza.

Municipal/municipio (y por extensión, municipalidad)-252,297-(comentario personal). Aparentemente, tanto en España como en Mesoamérica se usa el sinónimo "ayuntamiento" con más inclinación, mientras que el sinónimo preferido en los países del Cono Sur y otros de la América del Sur es "municipalidad".

Virgen del Carmen-10- Esto podría ser un detalle sin mayor transcendencia para algunos, sin embargo, se debe destacar que J. Samuel Valenzuela menciona en Chile: A Study Country, (95) que: "The votive temple of Maipú, also known as the Church of Our Lady Carmen, patroness of Chile". Esto deja en evidencia que la patrona de Chile, o como se denomina a la Virgen María en Chile, es la Virgen del Carmen. (cf.) Virgen de Guadalupe en México; de Santa Bárbara en Cuba, etc. Y, finalmente, si nos remontamos a la obra de Isabel Allende (10), nos daremos cuenta que la madre de Esteban Trueba, Ester, era beata de la Virgen del Carmen.

Vitrina-29, 324. 353-(DRAE y comentario personal). Al parecer, existe una tendencia en América Meridional a utilizar el término "vitrina" (de etimología gala, 
vitrine) paralelamente con vidriera (e.g. en Argentina), en vez de “escaparate" (del neendarlés medio [medieval], shaprade), el cual se usa asiduamente en Mesoamérica y en España (en especial para referirse cuando éste se encuentra en el exterior de una tienda, por ejemplo). Sin embargo, en Chile sólo se utiliza vitrina y algunos de sus derivados como "vitrinear", "vitrineo".

\subsubsection{Voces indígenas en La casa de los espíritus}

Camanchaca-39-(DRAE) Quichua. Niebla espesa y baja que reina en el desierto de Tarapacá. Y Editorial Antártica indica que "En el bosque de Fray Jorge [IV Región de Coquimbo-Norte Chico de Chile] se presenta un fenómeno bioclimático producido por la fuerte evaporación de las aguas del océano, que se condensa en forma de nubes bajas..., cuando al desplazarse al interior del continente son interceptadas por los cerros de la Cordillera de la Costa. Esta "camanchaca" mantiene asociaciones vegetales típicas de la selva valdiviana: olivillos, canelos y líquenes" (121).

Carpa-334-(DRAE) Del quichua, carppa, ramaje. Gran toldo que cubre un circo o cualquier otro recinto amplio. Tienda de campaña. 
Charqui-168-(DRAE) Quichua. Carne deshidratada y sazonada, especialmente salada que generalmente es de carne equina o bovina.

Chinchillas-176-7, 242-(DRAE) Aimará. Pequeño roedor, nativo de los Andes, aprox. del tamaño de una ardilla. Su piel se cataloga como de alto precio y excelente calidad.

Huacho-30-(DRAE) Quichua. Bastardo, hijo ilegítimo.

Palta-325-(comentario personal). Quichua. Voz que en América Central y el Caribe tiene "aguacate" como contraparte, cuya etimología proviene del náhuatl.

Papas-168-(comentario personal). Quichua. Tubérculo que en España se conoce como "patatas". El DRAE indica que patatas proviene "de la confusión de las voces americanas papa y batata", (mientras que en América se conserva la voz original "papa".

Pilchas-204-(DRAE) Mapudungún. Rural. Argent., Chile, Perú y Urug. Prenda de vestir, originariamente pobre o en mal estado.

Poncho-228, 295, 384-(DRAE) Mapudungún. Especie de manto cuadricular que tiene un orificio en el centro usado como prenda de vestir contra las bajas temperaturas.

Porotos-23. 360-(comentario personal). Quichua. Con su equivalencia en la Meseta Americana de "frijoles" y en la Península "judías" o "habichuelas." 


\subsection{Comentario general}

A través de esta breve selección general de palabras tomadas de la obra en estudio de Isabel Allende, nos podemos fijar en el hecho que este tipo de vocablos conlleva mucho más que una simple exposición de ciertas denotaciones y/o una o más connotaciones surgidas en cierto punto geográfico, sino que también se aprecia que entre estas palabras de uso peculiar como común en Chile, aluden directamente a costumbrismos y hechos fidedignos propios del acontecer chileno: su cuerpo policial (carabineros), una nave de gran transcendencia histórica (la Covadonga), referencia directa a un grupo indígena que existió y se desarrolló en el norte de Chile (los diaguitas), alusión a la patrona del mundo católico en Chile (la Virgen del Carmen). Ciertamente, estos factores nos llevan — sin mayor esfuerzo- al medio ambiente en donde se desarrollan los acontecimientos de La casa... de manera expedita. A parte de esta evidencia sociolingüística, los términos indigenistas corroboran una vez más la determinación del medio ambiente de la obra en cuestión, ya que estos vocablos son primordialmente del mapudungún, lengua del principal pueblo indígena chileno, y del quichua, lengua de los incas, que influenciaron siete (7) regiones del actual Chile (dividiéndose éste en doce [12] regiones geo-políticas). Inclusive, de acuerdo al Diccionario de la RAE, algunos de estos términos son precisamente usados en la isoglosa que conformara parte y fuera influenciada por el Imperio Incaico. Y por otra parte, el vocablo (hacer y pagar) "mandas" lo menciona el DRAE con límites 
geográficos determinados para su uso, es decir, limita su uso en Andalucía y Chile ${ }^{26}$. Justamente, como lo ha expuesto Oroz, se ha concluido a través de estudios lingüísticos que Chile comparte con Andalucía un cierto porcentaje de acepciones que resultan ser idénticas y otros casos relativamente similares (véase, páginas anteriores de esta tesis). ${ }^{27}$

Después de prestar atención a los mencionados vocablos que resultan ser de uso consuetudinario y de mucha significancia para el acontencer chileno, en las próximas páginas analizaremos la incidencia de vocablos pasivos (o, en su defecto, desconocidos) que presenta la obra, y así poder determinar hasta qué punto podría influir en su recepción este léxico pasivo que conforma parte del contenido de la obra de Isabel Allende en la comprensión de su mensaje; o bien si es irrelevante este aspecto léxico con respecto a la interpretación de la obra.

1.6. Lexicología: Vocabulario potencialmente pasivo o desconocido.

\subsubsection{Definición de lexicología}

En primer lugar, establezcamos un concepto en común de lexicología ${ }^{23}$. La lexicología trata el estudio de la naturaleza (forma, historia y significado de las palabras) del vocabulario de un determinado idioma, como por ejemplo, el español. Cada idioma presenta un número dado de palabras y expresiones idiomáticas que le componen. Por lo general, es prácticamente imposible afirmar la existencia de un hablante que domine 
íntegramente el completo y complejo léxico correpondiente a un idioma, debido a diversas razones, entre las cuales podrían contar las variedades existentes de lenguajes técnicos (o jergas) que identifican ciertos campos de especialización y conocimiento. La mayoría de las lenguas poseen un léxico muy amplio que contínuamente se modifica, dejando en estado arcaico y obsoleto ciertos vocablos, y se incrementa con la incorporación de neologismos, por ejemplo, la introducción de la nomenclatura de la alta tecnología contemporánea ${ }^{x}$. Y de manera concisa, David Crystal en su obra $A$ Dictionary of Linguistics \& Phonetics define lexicología como: is a term sometimes used to refer to the overall study of a language's vocabulary (including its history). (201). En cuanto al vocabulario, Crystal indica que: A distiction is sometimes made between 'active' and 'passive' vocabulary: the former refers to lexical items people use; the latter to words which they understand, but do not themselves use (373).

\subsubsection{Tipos de vocabulario del hablante}

Cada integrante de una comunidad lingüística dominará dos tipos de vocabulario que le caracterizarán. Uno — de menor mesura— es el conjunto de palabras y secuencia de palabras que utiliza en forma cotidiana, para componer los enunciados que le ayudarán a desenvolverse óptimamente dentro de las exigencias que impliquen un contexto dado. El otro — de mayor magnitud y extensión, pero de menor frecuencia en su uso- es aquel vocabulario que no emplea a diario, pero el hablante tiene la capacidad 
de reconocer, decifrar y entender tal conjunto de palabras, dentro de un contexto específico. Así, en esta sección, me referiré a dos términos, aludiendo a lo denominado como "vocabulario activo" y "vocabulario pasivo", pero prestando especial atención a este último.

\subsubsection{Vocabulario pasivo en contexto}

Con respecto al vocabulario pasivo, cabe señalar que a pesar de su desuso y perplejidad, éste puede aumentar — hipotéticamente- en su cantidad debido al factor contexto, lo cual le brindará al receptor la facultad de clarificar el significado de las nociones e ideas (que probablemente serían demasiado ambiguas para decifrar si éstas estuvieran en forma aislada-sin contexto) expuestas en un cierto enunciado o texto.

\subsubsection{Nociones globales de vocabulario activo en La casa...}

La casa... presenta un conjunto de vocablos activos que, en primera instancia, diferencian la dicción de la Península Ibérica de la del Continente Americano, debido esencialmente a los remanentes lingüísticos del castellano del siglo XVI y de antaño en general, que son calificados como obsoletos o arcaicos en la lejana España; mientras que en América Latina, tales arcaísmos aún poseen la virtud de conformar y caracterizar el lenguaje transplantado de Europa hacia América como partes del lenguaje cotidiano. Pero, no sólo la obra de Isabel Allende presenta evidencia lingüística de la selección de 
palabras correspondiente a los rasgos de una nación latinoamericana, sino que la obra también presenta vocablos que restringen la situación geográfica de la comunidad lingüística que se identifica en La casa..., a causa de la presencia de voces pertenecientes al quichua, las cuales han trascendido en el tiempo, y son —en la actualidad— de uso común y corriente en gran parte de las naciones de la región andina (si lo pudiésemos llamar así) que se han enriquecido con el aporte de giros quichuas, vale decir, Argentina, Bolivia, Chile. Ecuador y evidentemente Perú ${ }^{30}$ —como se ha indicado previamente. De esa manera, se puede apreciar el legado lingüístico que el Imperio Incaico ha dejado en el español contemporáneo, esto es, una lengua impuesta en el Continente, dejando a las lenguas ya existentes y establecidas en una condición rezagada.

Finalmente, se puede proseguir la restricción lingüística al considerar los elementos que ha proporcionado el mapudungún, es decir, la lengua del pueblo mapuche (o mejor conocido en el lenguaje vernacular como "araucano" o simplemente "mapuche"). El "mapuche" o mapudungún (siendo más exacto) también ha complementado o modificado la dicción de la comunidad linguística chilena por medio de ciertos términos que a pesar de tener una contraparte netamente española, en Chile se prefiere emplear la forma correspondiente al mapuche (salvo aquellos sustantivos derivados del mapudungún que componen la flora y fauna autóctonas de Chile, que son únicos). Y, cómo no terminar esta restricción de la isoglosa chilena, sin mencionar aquellos términos que han trascendido a través del tiempo; tal es el caso de ciertos 
términos que se podrían considerar, ya sea como arcaísmos exclusivos de Chile o bien como influencia de otros países europeos. Chile (al igual que otras naciones de la América Latina) estableció ciertos elementos que le han dado sus rasgos peculiares según patrones europeos desde el siglo XIX en adelante. Un ejemplo lo es el caso del sistema educativo secundario, es decir, el "liceo" (Allende. La casa... 149, 273), proveniente del francés "lycèe" o el mesero (o mozo) que en Chile se conoce comúnmente como "garçon."

\subsubsection{Vocabulario pasivo en La casa...}

Las siguientes páginas prestarán especial atención a la ejemplificación del vocabulario pasivo, que también podría manifestarse simplemente como vocabulario inactivo que para una mayoría es simplemente poco frecuente o, en su defecto, desconocido. Sin embargo, el manejo de las palabras a exponer a continuación podrían influir de cierta manera en la competencia para entender el discurso expuesto en el texto, es decir, su interpretación o validez hermenéutica; vale decir, si el conocimiento del significado puede influir en el flujo temático de la obra o no. Hipotéticamente, se podría afirmar que la presencia de estos vocablos no influyen en la percepción general del contenido de La casa..., ya que el lector se puede fácilmente percatar de las secuencias más relevantes, significativas y constructivas por medio del contexto, en general. Por lo tanto, estos términos no limitan la percepción de los acontecimientos que componen la 
obra de manera íntegra, ya que los elementos concomitantes al discurso aportan a la deducción de las acciones de cada secuencia temática en la obra.

Se proporciona una lista de vocablos de poca frecuencia o correspondientes a un léxico pasivo - hipotéticamente-, el cual ha sido tomado de $L a$ casa..., dando su número de página según su aparición en el texto.

Abisinios-237-(DRAE). Etíope. Natural de Abisinia o Etiopía de Africa.

Abyectas-48-(DRAE). Del latín abiectus. Despreciable, vil en extremo. II Humillado, abatido.

Acicalar -174-(DRAE). Del árabe as-siqal, el pulimento. Limpiar, alisar, bruñir, ... II Pulir, adornar, aderezar a una persona.

Batahola -76-(DRAE). Del italiano battagliola. Bulla, ruido grande.

Calañés-233-(Larousse). Dícese del sombrero de ala vuelta hacia arriba y copa baja. ॥ Sombrero de Calaña (localidad de la Provincia de Huelva, en Andalucía).

Daguerrotipo-17-(Larousse). De J. Daguerre, su inventor. Dispositivo que permite registrar una imagen sobre una placa yodada superficialmente.ll Imagen obtenida por daguerrotipia. (retrato fotográfico).

Ectoplasma-123-(Larousse). En parapsicología, cuerpo material que se desprende del médium en estado de trance. (Médium: persona con poder de percibir realidades 
parapsicológicas, y un sentido más estricto y más clásico, de percibir los mensajes de los espíritus).

Y, se podría extender el listado a otras palabras que probablemente pertenezcan a un vocabaulario pasivo para una gran mayoría, al menos de acuerdo a los resultados de mis informantes. Otras palabras presentes en $L a$ casa... cuyos significados ${ }^{31}$ no se reconocen con faciliadad fueron: gaznápiro-192-(Larousse): cándido, torpe; gaznate-173(Larousse): garganta; nácar-289-(Larousse): sustancia obtenida de la concha de ciertos moluscos, usado en la joyería; ojiva-393-(Larousse): arco que presenta un ángulo circular; oprobioso-256-(Larousse): que causa deshonor público; prurito-32-(larousse): deseo vehemente, ganas, inclinación; rictus-109-(larousse): contracción de la boca que da una expresión negativa); tumefacta-193-(Larousse): hinchado-a; yac-24-(Larousse): rumiante de largo pelaje, que vive en el Tibet).

A pesar de la riqueza lexicológica que presenta la obra de Allende ${ }^{32}$, este potencial vocabulario no ha representado ser una barrera para la asimilación de ideas y mensajes esenciales dentro de la obra. Definitivamente, el factor contexto ayuda grandemente en la asimilación de estos vocablos como parte intrínsica de un discurso dado. 
El siguiente Capítulo analizará la implicancia que tienen sustantivos ya no comunes como en la previa sección, sino que propios: toponimia y nombres de personajes claves en el desarrollo de los acontecimientos de La casa... 
Capítulo $2^{\circ}$ : Competencia socio-cultural/literaria

\subsection{Aspectos generales}

La competencia ${ }^{33}$ se determinará como el conjunto de habilidades lingüísticas y socio-culturales que fusiona a un grupo de personas a través de un pasado, experiencias, conocimiento general, costumbres y realidad objetiva —en cierta medida- en común. La competencia pragmática, así entonces, es crucial en la comunicación: verbal o escrita, ya que ésta representa la codificación adecuada y apropiada que transmite el emisor de un enunciado (o mensaje), y asimilada por el receptor. La codificación de enunciados implica el dominio tácito o adquirido por medio de la educación y formación idiosincrática personal de una gama de elementos sociolingüísticos de símbolos, signos, iconos, indicios, referentes; todos los cuales son fácil y naturalmente recepcionados, interpretados, o —en otras palabras- decodificados de manera eficiente para así establecer un contexto y discurso funcionales.

2.2. Evidencia textual en La casa... desde una perspectiva interpretativa

En La casa... se presenta una variedad de sutilezas semánticas tales como indicios y referentes que aluden e identifican ciertos rasgos, costumbrismos, hechos socio-políticos, ambientes geo-físicos y personalidades de la nación chilena. En este 
capítulo, intento demostrar la evidencia textual y, a la vez, sociolingüística, (i.e., pasajes) de la obra, requerida para ratificar mi hipótesis.

La evidencia no puede ser fácilmente vislumbrada por aquel lector que no está familiarizado con el acontecer de la nación chilena. Al disectar la obra o citar elementos de ésta, no pretendo crear una nueva obra ni acomodarla a mi gusto por medio de la interpretación aislada de partículas. La razón de esto es simplemente que aquellas partículas no podrían ser apreciadas si no estuviesen conectadas en su plena totalidad para así conformar el mosaico de la obra de Isabel Allende. En todo caso, cabe señalar que con o sin la asimilación de las alusiones impresas que reflejan al país de Allende. la obra tendrá su validez interpretativa —sea cual sea esta validez-. El tipo de asimilación o interpretación ha de variar, pero esto también es parte intrínsica de cualquier obra literaria. Sin importar la variedad de lectores de La casa..., cualquier lector estará presto a encontrar y esclarecer los elementos necesarios y esenciales para navegar a través de una secuencia de acontecimientos, incluyendo elementos espaciales y temporales. Estos elementos serán determinados o bien complementados por parte de cada lector. El lector es el que - para interpretar la obra- se transforma sutilmente (y, en casos, inconscientemente) en parte integral de la obra, percibiendo y sintiendo —en casos- las sensaciones de los personajes en forma paralela, anhelando y esperando lo que ha de acontecer en las siguientes páginas; sintiendo en forma personal lo que inquieta o alegra a ciertos personajes y así internalizando tales ideas; y, concomitantemente, 
internalizando la trilogía literaria clásica en cuanto a los fuelles fundamentales de una obra y su retórica (Bizzel 4): $\pi \alpha \theta 0 \int$ (pathos: sentimientos, emoción), $\varepsilon \theta 0 \int$ (ethos: carácter, actitud) y $\lambda$ o $\gamma_{0} \int(\operatorname{logos}$ : razón, objetividad) de la obra. Sin la participación o contribución sensorial, distintiva, idiosincrática y peculiar de cada lector, la obra no recobraría ningún ímpetu y permanecería plácidamente amorfa e inerte en su condición impresa.

Es un hecho que se puede encontrar una cantidad considerable de similitudes idiosincráticas como histórico-políticas entre los países hispano-parlantes (descartando a Guínea Ecuatorial, esto es), específicamente, entre las 19 naciones latinoamericanas, como por ejemplo: “descubrimiento" y conquista española, emancipación e independencia, poblamiento, inmigración europea (como lo es en varios países de América Latina), reducción y abuso de los habitantes indígenas, la demarcada distinción en el nivel de vida de la aristocracia-plutocracia en oposición a la lucha diaria de los más necesitados e indigentes. Otras semejanzas que tienen las naciones de América Latina se encuentra en el establecimiento de gobiernos dictatoriales. Cómo no se podría dejar de mencionar la involucración monetaria causante de secuelas atroces de tales regímenes de parte del Gobierno del País del Norte.

A pesar de todas las — ya mencionadas- aparentes similaridades, la sucesión de los acontecimientos históricos y descripciones del medio ambiente ciertamente 
pertenecen a Chile, todo lo cual está apoyado en la obra por numerosas referencias. Inclusive la propia autora ha reiterado que La casa... está inspirada en su país, su gente y sus costumbres, con pinceladas de su familia - mas no llegando a ser una biografía familiar - sino que simplemente una realidad decorada e impregnada con elementos ficticios (L.A. Lit.? by Willamette Media Center).

El lector desconocedor de la historia y vida socio-política de Chile — sin prejucio de la nacionalidad de éste- encontrará en la obra una narración ficticia, que probablemente se podría situar en cualquier país de habla hispana, es decir, América Latina.

2.3 Pasajes de la obra y ambiente general

El presente análisis proporcionará evidencia explícita que corroborará mi postulado hipotético. Habrá citas como las emitidas por el Conde Jean de Satigny que reflejan descripciones transparentes de Chile como lo exponen las siguientes líneas alusivas a dicho país en paráfrasis (mía):

Un norte árido y desértico rico en minerales (nitrato y cobre); un valle central fértil y con clima mediterráneo que brinda generosamente a sus habitantes un clima benigno, una bondad frutícola, una flora y fauna que viven en plena armonía con sus pobladores. Un sur que se desmiembra en islas bañadas con perenne 
garúa y precipitacions copiosas que más al sur -ya en la zona austral - se han convertido en glaciares y hielos que han perdurado por los siglos, e inclemencias climáticas que retan a diario a sus habitantes a entablar lucha con los elementos. Esa angosta y larga faja de tierra que mora tan remota y desolada se consuela con la compañía y camaradería que le otorga el majestuoso escenario de montañas y volcanes de la magistral Cordillera de los Andes, que vela por este país en su integridad longitudinal de más de 2.600 millas de norte a sur, que en el oriente limita con la República del Plata.

De esa manera, esta sección consistirá esencialmente en el reconocimiento y reconstrucción de pasajes y citas alusivas a ambientes costumbristas, climáticos, históricos y políticos — propiamente tales— de Chile.

\subsubsection{Citas ejemplificadoras ${ }^{34}$}

1. Esteban estaba trabajando en las minas del Norte...vientos del desierto, doblones del desierto y joyas de los incas (-13-). Referente: El norte de Chile se caracteriza por su riqueza mineral. En esta zona, se encuentra uno de los desiertos más 
áridos del mundo, el Desierto de Atacama. Y, finalmente, todo el norte de Chile actual estuvo bajo dominio de los incas.

2. ... anunciaba los temblores con alguna anticipación, lo que resultaba muy conveniente en ese país de catástrofes (-15-) Ref.: Chile, un país que tiene alrededor de 50 volcanes activos, ha sido víctima de atroces temblores a través de su historia; e.g. el terremoto de 1939 que tuvo su epicentro en las regiones VII y VIII, dejando 608.270 damnificados en donde también hubo casos de fiebre tifoidea (30.000 muertos en total); y en 1960 dos terremotos afectaron al país, entre los cuales se encuentra el mayor sismo que ha experimentado el país, es decir, el terremoto del 22 de mayo de 1960, de grado 9.5 en la escala de Richter. El epicentro fue la ciudad de Valdivia; causando 5.000 muertes (Urrutia de H. 230, 286; Torechio 171).

3. Al despuntar la primavera, las hizo trasladar al Parque de los Desfiles. un descampado enorme donde se juntaba el pueblo a ver marchar a los militares durante las_Fiestas Patrias..." (-19-) Ref.: En Chile, es decir, en el Hemisferio Sur, se da la bienvenida a la primavera en septiembre; este mes que coincide con la celebración de las Fiestas Patrias (conmemorando la Independencia Nacional), el 18 de septiembre, y el 19 del mismo mes, el Día del Ejército de Chile con un desfile en el Parque Cousiño de Santiago.

4. Vastos campos tendidos al pie de la Cordillera, fértiles campiñas de viñedos, de trigales, de alfalfa y de maravilla... (-52-) Ref.: La geografía de Chile, un país tan 
estrecho, comprende la Cordillera de los Andes, Depresión Intermedia y la Cordillera de la Costa. Es precisamente la depresión intermedia del centro-sur del país que presenta fértiles valles cubiertos por un clima mediterráneo que le ha dado la posibilidad de cultivar una variedad de frutas y cereales propios de la Europa mediterránea. (véase, ilustración alusiva en Anexo). Además, este pasaje nos hace remontarnos a la siguiente cita de Editorial Antárctica en la cual se hace alusión al Valle de Aconcagua y el Valle Central:

El clima [mediterráneo] y la calidad del suelo convierten los campos de esta región [V o del Acancagua] en los más fértiles del país. Sus tierras han sido cultivadas desde antes de la llegada de los españoles donde los indigenas obtenian abundantes cosechas... Existen también miles de lectáreas plantadas de vid, destinada a la producción de uva de mesa y para vinos, con un total de 7.000.000 de litros anuales. (159)

La cifra arriba mencionada corresponde a la producción vinícola de principios de la década de los '80. Otros productos caraterísticos de esta zona son: papayas, membrillos, chirimoyas, paltas, nueces, etc.; y en cuanto a su producción de cereales y leguminosas se destaca su alta producción anual en miles de toneladas de trigo, maíz, porotos, papas, etc. Otra región que sobresale por su producción agropecuaria es la VI Región, o mejor dicho, las zonas de la Cuenca de Rancagua y el Valle Central correspondiente a Colchagua. Y Editorial Antártica señala lo siguiente: 
Pese a su tanaño, los rendinientos agrícolas son los mejores del país... Otro aspecto que debe destacarse es el incremento de los cultivos industriales como...maravilla...En cuanto a su producción de vinos, bordea los 90.000.000 de litros anuales, además de aguardientes famosos... [y finalmente], hay grandes extensiones de naranjales $y$ limonares, cítricos que requieren de un clima mediterráneo sin heladas, como ocurre en esta zona. (215)

5. Un ejemplo para este continente de indios y de negros,... Este es un país diferente, una verdadera república, tenemos orgullo cívico... (-73-) Ref.: Prosigo haciendo uso de citas provenientes de la obra de Editorial Antártica, Chile a color, geografía:

En el conjunto de América Latina la población de nuestro país se distingue por la homogeneidad étnica y cultural de sus habitantes que comparten aproximadamente las mismas características físicas $y$ psicológicas y hablan la misma lengua... Esta condición uniforme se explica porque el pueblo chileno tiene un fondo mestizo derivado directamente de la mezcla entre indigenas [:] diaguitas, atacameños, picunches, mapuches, huilliches; y españoles[:] extremeños, castellanos, andaluces, vascos, principalmente a lo largo de los siglos coloniales. Este proceso no fue alterado como en otras partes por la 
afluencia masiva de elementos africanos ni por grandes movimientos de inmigrantes europeos; salvo la llegada de ingleses a Valparaíso, de algunos alemanes..., de yugoslavos..., y más recientemente de españoles, árabes, italianos, y judios en el centro de Chile. En cuanto al elemento indígena, el línico grupo de cierta importancia hoy integrado cultural y económicamente al país, es el mapuche de la antigua frontera que alcanza a unas 300.000 personas. (28)

Finalmente. Chile se jacta por haber tenido un periodo de más de 150 años de democracia. (Chile: Rough Guide by BBC). O, como lo expone Paul W. Drake (en Chile: A Country Study): From one of the most neglected outposts of the Spanish Empire, Chile developed into one of the most prosperous and democratic nation in Latin America. (3)

6. En las provincias del Norte la quiebra de las salitreras había dejado en la miseria a miles de trabajadores...(-131-). Ref.: El Norte de Chile tuvo un apogeo salitrero desde mediados del siglo XIX hasta la Primera Guerra Mundial, por lo cual la economía nacional, o más específicamente, las exportaciones nacionales dependieron grandemente de los inversionistas ingleses (Hudson 10-30).

7. Suspiró, conmovido por aquella naturaleza pródiga que podía reunir en el más olvidado país de la tierra, todos los climas de su invención, la cordillera y el mar, los valles y las cumbres más altas, ríos de agua cristalina....(-177-). Ref.: Es frequente 
referirse a Chile como un país situado al fin del mundo, aislado por barreras naturales; y debido a la longitud de su territorio, posee una gama de climas distintivos: subtropical, árido, mediterráneo, tundra, sub-polar.

8. La cúpula de fierro que habian construido los ingleses imitando la Estación Victoria, en los tiempos en que tenían la concesión de los ferrocarriles... y los cargadores con sus gorras oscuras con la insignia de la corona británica... (-85-) Ref.: Esta descripción refleja la Estación Central de Santiago cuya cúpula metálica emula a la estación inglesa, Victoria. Por otra parte, Bizzarro señala que: "Most of Chile's subsequent railway construction [desde 1863] until World War I was done by the British..." (428). Aparte de eso, Torechio indica que: "Administró el servicio [ferroviario] The Chilean Transandine Railways Co., hasta que en 1934 pasó a Ferrocarriles del Estado [de Chile]" (68). (El Anexo, ilustraciones alusivas, también presenta una fotografía de la Estación Central en el área céntrica de Santiago).

9....para darle al festín la apariencia de una modesta reunión familiar, porque toda extravagancia era una prueba de chabacaneria y condenada como un pecado de vanidad mundana y un signo de mal gusto, debido al ancestro austero y algo lúgubre de aquella sociedad descendiente de los más esforzados emigrantes castellanos y vascos. (-92-) Ref.: La sobriedad en la sociedad chilena es un aspecto que se valora altamente (Paula 20). Y, desde otro punto de vista, Bizzarro indica .... que los inmigrantes vascos en Chile llegaron —en un momento dado- a componer el $45 \%$ de 
la totalidad de inmigrantes europeos en Chile, y que éstos han sido un pilar de mayor relevancia en la formación del carácter tranquilo y esmerado del chileno (55-6).

10. ... y una benigna fauna que permitía pasear con toda confianza, con la certeza de que no aparecían víboras venenosas o fieras hambrientas, y... (-177-). Ref.: La fauna de Chile es relativamente inofensiva, salvo por una especie de arácnido de trigales y el alacrán, cuyas mordidas son venenosas, empero, no son mortales (Editorial Antártica 154, 211).

11... cuando pasó el tren del nuevo candidato del Partido Socialista, un doctor miope y carismático que movía a las muchedumbres...(-185-) Ref.: Precisamente, Fernando Alegría en su obra, Allende: A Novel, indica que el candidato presidencial, Salvador Allende recorrió gran parte del país en una locomotora acicalada para su campaña presidencial (127-146).

12....[Jaime] Estaba leyendo los sonetos de amor del Poeta, que para entonces ya tenía renombre mundial....el poeta solía sentarse a la hora del té a hablar sobre canciones desesperadas... (-225-). Ref.: Con gran facilidad, estas líneas llevan a pensar en Pablo Neruda (Premio Nobel de Literatura, 1971) con su famosa obra Veinte poemas de amor y una canción desesperada (1924) y Cien sonetos de amor (1959).

13. ...provincia del Norte... [el Conde Jean de Satigny] Pudo alquilar una antigua mansión que habia pertenecido a una de las grandes fortunas de los tiempos del salitre, antes que se inventara el sustituto sintético que envió toda la región al 
carajo... (-237-) Ref.: La mayoría de la ciudades del Norte de Chile muestran hoy el remanente de aquellas mansiones y casas señoriales que son fiel reflejo del apogeo del salitre desde el siglo XIX hasta las primeras décadas del XX. Sin embargo, la ubicación del nuevo hogar de Blanca Trueba y Jean de Satigny en el Norte, bien podría ser la ciudad de Calama, la cual se sitúa en la II Región de Antofagasta, ubicándose en la cercanías de los mencionados [en la obra de Isabel Allende] valle lunar ${ }^{35}$, y Museo de Arqueología ${ }^{36}$.

14. Allí [el Senador Trueba] se juntó con otros políticos, algunos militares y con los gringos enviados por el servicio de inteligencia, para trazar el plan que terminaría el nuevo gobierno: la desestabilazación económica, como llamaron al sabotaje. (-325-) Ref.: La grabación de video, Chile in Women's Hands, claramente establece la involucración del gobierno estadounidense y, por ende, la C.I.A. para terminar con la presidencia de Allende a cualquier costo. El sabotaje de la economía nacional resultó una táctica efectiva: las grandes distribuidoras de abarrotes fueron instruidas para acumular todos sus bienes, y los camioneros —cruciales para el transporte de bienes de norte a sur del país - recibieron una remuneración en dólares para llevar a cabo su plan para paralizar el país. Bizzarro, por otra parte, explícitamente expone información que coincide con las tácticas tomadas por el ex-presidente de la nación (1964-70) y senador, Eduardo Frei Montalva (208-10), durante la presidencia de Allende. 
15. En las pulcras casas del Barrio Alto abrieron las botellas que habian estado esperando durante tres años y brindaron por el nuevo orden (-352-) Ref.: El gobierno de Allende se extendió sólo por tres años de 1970 a 1973 . Y, por otra parte, quienes celebraron el derrocamiento del gobierno izquierdista fueron ciertas facciones de la clase alta, que vivían precisamente en el Barrio Alto de Santiago (Providencia, Vitacura, Las Condes. La Dehesa; [véase, mapa en Anexo de este trabajo; y películas, The House of the Spirits y Sweet Country]).

16. Mi nieta Alba, en cambio, vio perfilarse al dictador mucho antes que yo [Esteban Trueba]. Lo vio destacarse entre los generales y gentes de guerra... Es un hombre tosco y de apariencia sencilla, de pocas palabras, como un campesino. Parecía modesto y pocos pudieron adivinar que algún día lo verian envuelto en una capa de emperador, con los brazos en alto para acallar a las multitudes acarreadas en camiones para vitorearlo, sus augustos ${ }^{37}$ bigotes temblando de vanidad... (-357-) Ref.: Como se indicará más adelante Augusto Pinochet Ugarte, a través de su vida militar, ascendió paulatinamente a diversos rangos militares, llegando ulteriormente a su cúspide como General. Por otra parte, cabe indicar que en los recorridos de Pinochet por las provincias de Chile, era común ver a buses y camiones repletos de campesinos a quienes se les remuneraría como cualquier otro día de trabajo por ir a incremetar la muchedumbre que aplaudía la visita presidencial (comentario personal). 
17. ... Estas son las cosas que desprestigian a la Junta Militar en el extranjero y dan pie para que las Naciones Unidas comience a joder con los derechos humanos, yo al principio no quería oír hablar de muertos, de torturados, de desaparecidos, pero ahora no puedo seguir pensando que son embustes de los comunistas, si hasta los propios gringos, que fueron los primeros en ayudar a los militares y mandaron sus pilotos de guerra a bombardear el Palacio..., ahora están escandalizados por la matanza... (-396-) Ref.: Durante el gobierno de la Junta militar, diversos países rompieron relaciones diplomáticas y comerciales con Chile debido a la denuncia categórica de las violaciones de los derechos humanos cometidas bajo la dictadura de Pinochet. Y fue uno de los conspiradores del Golpe de Estado, es decir, Eduardo Frei Montalva, quien después de tantas atrocidades y asesinatos cometidos se retractó de su idea original de apoyar el pronunciamiento militar, mientras —-según su plan — todo pronto volvería a su normalidad, es decir, el gobierno en manos de su Partido Conservador o Demócrata-cristiano (Bizzarro 208-9).

Los diecisiete pasajes previamente citados reflejan sin mayor duda aspectos del escenario geo-político de Chile; todo lo cual será asimilado para todo aquel que tenga cierto grado de conocimiento sobre la historia y sociedad chilena. 
De citas generales, ahora me referiré a datos más concretos y específicos como personajes peculiares y situaciones geográficas y/o ambientales determinadas de la obra en estudio.

\subsection{Técnica Roman à Clef:}

Con la intención de demostrar la aplicación de la técnica Roman à Clef y, así, corroborar con el postulado de esta tesis, es decir, considerarla como una manifestación directamente relacionada con el país de Isabel Allende, mencionaré a ciertos personajes que se destacan simbólicamente en la obra en estudio así como también a aquellas personalidades de la vida real con las cuales se les puede comparar.

\subsubsection{Definición de Roman à Clef:}

M.H. Abrams define este recurso literario, por una parte, como: (French for "novel with a key") is a novel in which the knowing reader is expected to identify within the fiction, and despite altered names, actual people of the time. (165). Y, The Oxford Encyclopedic English Dictionary lo define por otra parte como: A novel in which real persons or events appear with invented names. Así entonces, empezaremos con una selección de personajes que aparecen en La casa..., y que sobresalen de manera simbólica en la historia socio-política de Chile, que -en general- aluden a personalidades, especialmente, vinculadas con el Golpe de Estado. 
2.4.2 Personajes ficticios de la obra como reales:

1. El Candidato/ Compañero Presidente $(-164,185,316-7,327-)=$ Salvador Allende G. Precisamente, este personaje se refiere al Dr. Salvador Allende Gossens de quien Donato Torechio señala lo siguiente:

Nació el 26 de julio de 1908, en Santiago de Chile. Se recibió de médico-cirujano en 1932. Desde joven perteneció al partido Socialista, del cual llegó a ser secretario general y presidente del Frente Nacional del Pueblo. Lanzó su candidatura presidencial en los comienzos de 1952, 1958 y 1964, siendo derrotado sucesivamente.... En 1970 fue elegido Presidente de la República con el $36.2 \%$ de los votos, por lo que debió ser confirmado por el Congreso. (16)

Además, The American Encyclopedia Grolier señala objetivamente lo siguiente sobre el polémico desenlace de Salvador Allende:

...His administration nationalized many industries (including the copper mines, in which the U.S. business had major investment) and accelerated land reform. These measures antagonized right-wing elements, and 
severe economic problems, aggravated by strikes, resulted in more widespread disaffection, which was encouraged by the U.S. Central Intelligence Agency [C.I.A.]. Allende died on September 11, 1973, during a military coup that overthrew his government. His successors declared that he had committed suicide; [whereas] his supporters claimed that he was murdered.

Cabe recalcar que la obra previamente mencionada de Torechio fue publicada [en 1986] durante el régimen militar de Augusto Pinochet. Esto resulta crucial en el desmentimiento de la muerte de Allende, ya que otras fuentes indican ambivalentemente que fue cobardemente derrocado (cf. Alegría 282-6), al igual que Isabel Allende de en La casa... (349) Contrariamente a los datos generalizados, el documental televisivo "Americas: Chile In Women's Hands," señala que el gobierno socialista-marxista de Salvador Allende fue derrocado debido a un complot financiado con fondos de los EE.UU. y organizado por la C.I.A. en conjunto con las Fuerzas Armadas de Chile y un gruptisculo de la oligarquía nacional. Este complot se logró a través del sabotaje de la economía nacional, lo cual causó un descontento marcado en la población y un consecuente caos de la economía nacional. Fondos estadounidenses incentivaron huelgas como la de los "camioneros", se efectuó una serie de cierres de cuentas bancarias y se produjo un estancamiento en la producción nacional. 
2. Oficial-coronel-comandante-general Hurtado/Dictador $(-237,291,325,356-7,375-)=$ Augusto Pinochet Ugarte. Donato Torechio señala en Diccionario histórico... (137) lo siguiente sobre Augusto Pinochet Ugarte:

Nació el 25 de noviembre de 1915. Egresó de la Escuela Militar en 1936. como alférez de infantería. Teniente $1^{\circ}$ en 1942 y capitán en 1946. Alumno de la Academia de Guerra en el período 1949-1952, de la cual se graduó como oficial de Estado Mayor. En 1953 ascendió a mayor y pasó a Arica al Regimiento Rancagua. En 1956 estuvo en la Misión Militar en Quito. Comandante del regimiento de infantería $N 7$ Esmeralda de Antofagasta, en 1961. Autor de varios textos de temas históricos y castrenses. El 11 de septiembre de 1973 integró la Junta de Gobierno, tras la caída de Allende.

La especificación de la ascensión de los diversos rangos militares resulta importante, ya que Isabel Allende presenta en su obra a un personaje de apellido Hurtado que aparece con diferentes grados militares a lo largo de la obra.

3. Pedro Tercero García $(-149,326-)=$ Víctor Jara. Patricia Hart en su obra, Narrative Magic In The Fiction of Isabel Allende: The Legend of "el cantante", explica objetiva y 
claramente la intención de Isabel Allende al sólo mencionar a Víctor Jara en forma simbólica, ya que la historia de Pedro Tercero García no coincide exactamente con la de Jara; pero sí que coincide el legado potencial que Víctor Jara pudiese haber logrado al difundir —a través de su canto popular-- verdades e injusticias socio-políticas que afectaban a la nación chilena; todo lo cual resultaba como un medio más expedito y adecuado para alcanzar a la población menos educada e informada de aquel entonces. Las siguientes citas de Patricia Hart ejemplifican este punto de vista:

If Jara's influence was so great, then why does Allende neglect to include him as a spirit or a character in her book? In order to postulate a response, it is necessary to step briefly outside the confines of the text, but before we do, let us look at what is within. In fact, Allende has created a character who has some superficial resemblance to Victor Jara. This character is, of course, Pedro Tercero Garcia, lover of Blanca's and former peon on the land of Esteban Trueba. Both Jara and Pedro Tercero Garcia rise from poverty to become a number one protest singer in the country -and a big similarity that is! If you mention to virtually anyone in Latin America the number one protest singer of Chile, 
steeped in folk traditions, a man who reached his greatest popularity just before the coup, the listener will immediately respond with the name of Victor Jara. (Hart, 100)

Patricia Hart prosigue indicando las similitudes que hacen de Pedro Tercero García un fiel representante símbolico de Víctor Jara, a quien le despojaran su fortuna más preciada, ya que con ella producía su cantar:

Another, much more convincing piece of evidence in support of the deliberate evocation of Jara within the text is the detail that as a young man, Pedro Tercero has three fingers from his right hand cut off by an enraged Esteban Trueba wielding an ax. ... In spite of his mutilation, Pedro Tercero has the greatness of spirit to go on making music. He learns how to strum his guitar with the thumb and forefinger of his right hand and despite his handicap arrives at a "vertiginosa popularidad que ni él mismo esperaba" [Allende 293]. 
4. El Poeta $(-188,210,225,268,367-)=$ Pablo Neruda. El catedrático chileno, Donato Torechio, se refiere a Neruda señalando que:

Nació el 12 de julio de 1904. ...Considerado como uno de los más altos exponentes de la poesía castellana. Desempeñó funciones diplomáticas en Birmania, Java, España, México, y Francia. Senador por el partido Comunista en 1944; a consecuencia de sus ideas políticas fue expulsado del Senado en 1948, debiendo huir del país. Algunas de sus obras más importantes son: "Crepusculario" (1923), "Veinte poemas de amor y una canción desesperada" (1924), "Residencia en la tierra" (1933),... ["Cien sonetos de amor", 1959]. Recibió en 1945 el Premio Nacional de Literatura y el 21 de octubre de 1971, el Premio Nobel de Literatura. Falleció el 23 de septiembre de 1973. (118)

5. Senador Trueba $(-215,354-)$ : Representa probablemente a Eduardo Frei Montalva, quien fue uno de los conspiradores y agitadores del Golpe de Estado, acudiendo al gobierno estadounidense (por segunda vez, ya lo había hecho para su campaña presidencial en 1964) para provocar el retiro de Allende de la Presidencia. Además. Frei 
Montalva fue uno de los fundadores del Partido Demócrata Cristiano, y Presidente de Chile desde 1964-70. Por otra parte, cabe señalar que Frei Montalva en 1935 colaboró en la organización de la facción de la juventud del Partido Conservador (Bizzarro 2089).

6. (Tío) Jaime del Valle (-316-): Este personaje ilustra a la comitiva de médicos que generalmente acompañaba al Presidente Salvador Allende en el Palacio de la Moneda, el palacio presidencial. En especial, la compañía de estos médicos resulta considerablemente crucial y polémica al tratar el tema de la muerte de Allende, ya que fueron algunos de ellos que acompañaron a Allende en sus últimos instantes de vida, y lo que es más aun, varios de estos médicos como los guardias personales de Allende perecieron y los otros se rindieron ante los soldados que irrumpieron el Palacio de la Moneda (Alegría 263-86; Pinochet 123-46).

7. Sacerdote (cura) Alemán (-242-) = Padre Gustavo Le Paige Walke. Una vez más, uno percibe los cambios sutiles de los personajes o, mejor dicho, cambios en sus datos personales, como es el caso de la nacionalidad de este sacerdote que aparece en la obra como alemán en vez de belga, que tuviera tal transcendencia para el patrimonio y conservación del legado de los pueblos indígenas del Norte de Chile. Además, Torechio se refiere a él. indicando que: 
Nació en Bélgica el 24 de noviembre de 1903. Sacerdote, llegó a Chile el 5 de septiembre de 1953. Dedicó sı entusiasmo y conocimientos a la creación del Museo Arqueológico de San Pedro de Atacama, actualmente de la Universidad del Norte. Se le concedió la nacionalidad chilena [por decreto ley]. Murió el 19 de mayo de 1980. (95)

8. Vecinos Ugarte (-125-): Aquí cabe señalar que Ugarte es el apellido materno del actual Comandante-en-Jefe del Ejército de Chile y ex-Jefe de la Junta de Gobierno [o dictadura] de Chile (1973-90). Es una alusión tal vez vaga, pero concuerda con el trasfondo familiar de A. Pinochet Ugarte que residía en el barrio acomodado de Santiago, que paulatinamente se desplazara hacia las laderas de la Cordillera (Providencia, Las Condes, Vitacura, La Dehesa. [Véase, plano alusivo en el Anexo de los sectores citados de Santiago]). Cabe indicar que la consideración de la siguiente paráfrasis de La casa..., resulta esclarecedora: Los vecinos Ugarte no creyeron en el cuento del fantasma español, por lo cual no consideraron el deshacer una de sus paredes para buscar aquel tesoro presagiado por Clara (125). El hecho de que los Ugarte fuesen los vecinos de Clara implica que, también, vivían en el "Barrio Alto de la Capital". Y, por otra parte, se debe recordar que fue precisamente un grupo de la oligarquía (esto es, pertenecientes al Partido Conservador o Demócrata Cristiano) los 
que fueron ayudados por la C.I.A. para derrocar el gobierno de Allende; todo lo cual nos brinda una conexión entre "estos vecinos" y su respectivo estrato socio-económico y que se apelliden igual que Augusto Pinochet Ugarte, siendo Ugarte un apellido no muy común (comentario personal).

9. Blanca (-a través de toda la obra, esp. en los últimos capítulos-): Este personaje presenta un simbolismo más general, ya que podría evocar a aquellas mujeres de la clase media/media-alta de Chile, que a pesar de su holgado estrato socio-económico estaban al tanto del padecer de los partidarios de la izquierda durante las secuelas del golpe de estado; y por ello, algunas de ellas se esforzaron por prestarles ayuda a los que padecían de hambre y a los que estaban siendo perseguidos por el ejército. La ayuda de estas mujeres —en casos- consistió en la búsqueda de escondites y refugio, o bien en el uso de sus contactos para sacar al mayor número de personas --que corrían peligro de ser encarceladas y torturadas - del país a través del Obispado/Vicaría y/o embajadas en Santiago. (Paula 204-224). Muchas mujeres fueron aprehendidas y torturadas vilmente por manos del ejército de la Junta militar, por su buen obrar hacia sus prójimos.

Así, a través de la obra de La casa..., nos podemos percatar que la autora ha mencionado una serie de personas que de una manera u otra fueron afectadas por el Pronunciamiento Militar. Y, si extrapolaramos, qué mejor misión pudiera cumplir una 
novela de denuncia como de homenaje a aquellos que padecieron del dolor y otros a quienes se les despojo de sus vidas, siendo mencionados en forma simbólica, ya que era evidente que una obra de tal contenido político no hubiera podido ingresar a Chile, durante los años de la dictadura (1973-1990). De hecho, Isabel Allende nunca fue conocida como escritora en la década de los ‘ 80 por la población chilena como fuera en Europa, por ejemplo, lo que se debió al contedido "subversivo" de sus obras según las prohibiciones de la Junta.

La técnica Roman à Clef en esta obra, al decifrar quien se oculta detrás de cada personaje supuestamente ficticio, nos permite adentrarnos a una realidad socio-política que incluso fue negada —en un tiempo dado-y manipulada a los mismos integrantes de la población chilena, presentes en el país. 
Capítulo $3^{\circ}$ : Acercamiento hermenéutico (o interpretativo):

\subsection{Definición de hermenéutica}

La hermenéutica, que originalmente se limitaba al estudio de la interpretación bíblica, desde las primeras etapas del sigo XX ha cobrado un nuevo realce en el campo de la literatura, esto es, su interpretación. El nominal greco —compuesto del "dios mensajero", $\mathrm{H} \varepsilon \rho \mu \varepsilon \int\left(\right.$ Hermes $^{39}$ ), y del sufijo $\alpha \tau \imath \kappa o \int$ (atikos) que designa "el arte o estudio científico de..." - ha presenciado su desplazamiento del restringido estudio de la interpretación de las Escrituras a toda obra literaria, en el presente. Esta rama se ha forjado gracias a filósofos alemanes, primordialmente, por lo cual no se podría dejar de mencionar a personalidades como Edmund Hussler, Martin Heidegger, Schleiermachen, Wilhelm Dilthey, Hans-Georg Gadamer, y E.D. Hirsh Jr., que como en una cadena unida por partículas - como por la física - han transmitido y hecho transcender sus filosofías, modificando y precisando el significado y objetivo y utilización práctica de la aplicación de la hermenéutica en la obra literaria. Lo que uno de ellos hubiese propuesto, sería retado y alterado por otro, para finalmente establecer y refinar cuidadosa y paulatinamente el objetivo que se persiguía. Dicha "cadena filosófica como cognitiva" cobra su significado al considerar el hecho que Husserl haya sido el instructor de Heidegger; y que los predecesores de Heidegger, hayan sido 
Schleiermachen y Dilthey y a su vez, el sucesor de éstos, Hans-Georg Gadamer (Eagleton 54-90).

3.2 Perspectiva hermenéutica en La casa de los espíritus

Al tratar de incorporar teorías literarias contemporáneas para facilitar la interpretación de $L a$ casa... de Isabel Allende —en este caso particular-, resulta imprescindible el mencionar tres teorías primordiales que bien representan un espectro amplio y variado en relación a la manera de percibir una obra literaria y la manera de determinar su validez interpretativa intrínsica para lo cual nos basaremos en las perspectivas que expone Terry Eagleton.

3.3 Aspectos de la validez interpretativa según T. Eagleton

Terry Eagleton presenta en su obra, Literary Theory, (3) tres aspectos principales que abarcan la materia de la validez de la obra literaria; es decir, Eagleton se centra en el estudio de la Teoría Literaria contemporánea para lo cual emplea las siguientes ramas de estudio: fenomenología, hermenéutica y la teoría de la recepción.

\subsubsection{Fenomenología}

En primer lugar, me referiré a la fenomenología. Esta rama establece que la obra literaria es una mera dualidad compuesta por sujeto y objeto, en la que el sujeto es 
representado por el texto en sí y todo el discurso literario que éste encierra en sí. El objeto se refiere al lector que debe percibir un significado que yace impreso en los folios de una obra determinada. En otras palabras, el significado de la obra debe encontrarse dentro del contexto de la obra sin extrapolar ideas o conjurar acciones que no se describen en ésta. El lector tiene sus confines en la obra en sí, sin poder explayarse a remotas dimensiones o ambientes impropios a lo que la autora ${ }^{40}$ ha difundido $y$ manifestado en su literatura impresa. Por otra parte, el inglés J.A. Cuddon se refiere a 'fenomenología' en su Dictionary of Literary Terms and Literary Theory de la siguiente manera: [It is] A method of philosophical inquiry which lays stress on the perceiver's vital and central role in determining meaning (705).

\subsubsection{Hermenéutica}

En segundo lugar, aludo a la relevancia de la hermenéutica (que más adelante exploraré más detenidamente, ya que son sus premisas las que concuerdan con mi postulado interpretativo de La casa... Los pilares esenciales de la hermenéutica se basan en dos conceptos primordiales: meaning and significance (que para propósitos prácticos, los traduciré de la siguiente manera), i.e., significado intrínsico de la autora y significado atribuido por el lector, respectivamente. Esta rama establece que el fin inherente de la interpretación literaria es maravillarse al encontrar el significado y la intención pragmática originales de la autora. Es decir, la autora tenía una realidad y 
propósito en mente que transmitir al momento de escribir, y éstos son los que el lector debe osar vislumbrar y no fabricar realidades someras que se distancien del mensaje y esencia temática de tanto el texto como de la autora. (Estos aspectos se han presentado de acuerdo a los fundamentos que expone Hans-Georg Gadamer sobre la 'hermenéutica' en la obra de Hugh Silverman).

\subsubsection{Teoría de la recepción ${ }^{41}$}

En tercer lugar, haré mención a "reception theory". Esta teoría expone que la obra en sí es una materia — de cierta manera— por procesar y activar por parte del lector. La obra ha de recibir el soplo vital por parte del lector y éste es quién debe otorgarle una validez única a la obra. Vale decir, según esta teoría, la validez de la obra literaria depende del conjunto de experiencias vividas por el lector y de su libertad absoluta de atribuir significado a lo impreso de manera idiosincrática. La obra literaria como una manifestación artística no puede imponer parámetros interpretativos sino que —más bien — ser una fuente de ideas translucientes para ser asimiladas con matices que el lector moldeará y determinará.

Cuddon en su obra, abarca el tema de la 'teoría de recepción' haciendo mención a Hans Robert Jauss, añadiendo que:

....he suggests that literary work should be studied in terms of the impression or impact it makes on its contemporary audience, and that 
literan' value is judged according to how much the view of the text alters over time [....]. So there is a kind of balance and co-operation between text and what it provides and what the reader contributes. However, all readers are different and therefore may be supposed to bring a different response to any text. (778)

3.4 Acercamiento hermenéutico en La casa de los espíritus

El acercamiento hermenéutico es el que a mi juicio realza mi postulado de manera integral, ya que éste estipula que la misión del lector es el poder percibir el mensaje original de la autora. Al ocurrir esto, la obra ha cumplido su propósito de ser, en primera instancia. Desde otro punto de vista, siendo La casa... una manifestación de la literatura latinoamericana, se puede apreciar también la existencia de ciertos elementos relacionados con el concepto de literatura de denuncia o como lo expresa el término francés autheurs engagés, es decir, las obras literarias de aquellos escritores moral y socio-políticamente comprometidos con una sociedad dada, quienes denuncian irregularidades de una nación o de cierto sistema gubernamental ${ }^{42}$. Vale decir, entonces, si no se aplicase la noción de la validez interpretativa que implica la hermenéutica, ¿cómo podríamos estar conscientes de aquel primer presidente socialista, que triunfó gracias a la coalición de los partidos de la izquierda, que fue incivil y cobardemente derrocado?; ¿cómo podríamos identificar a aquellas mujeres como Blanca Trueba del 
Valle que sufrieron y que fueron abusadas tan salvaje y vilmente por la fuerza militar?; ¿cómo podríamos relacionar los intereses económicos basados en la riqueza mineral de un país sudamericano? —que primeramente atrajo a inversionistas ingleses y posteriormente a norteamericanos quienes, de un modo u otro, se han carecterizado por monopolizar los dividendos y la dirección del factor lucrativo a la par con la élite nacional—; ¿cómo podríamos transportarnos a aquel lejano rincón separado del resto del mundo, de valles fértiles y de copiosas viñas: productos de un benigno clima mediterráneo, en donde el sofista y cursi Conde de Satigny desposa a "aquella heredera sudamericana"? (Allende. La casa... 205); ¿cómo podríamos asimilar la relevancia e impacto socio-políticos que tuviera un personaje como Pedro Tercero García? —es decir, su rol como agitador pensante de los campesinos y trabajadores a través de sus ideas y de sus creaciones como canta-autor, lo que se refleja fielmente en el desenlace de Víctor Jara, quien como Pedro Tercero se le haya amputado las extrimidades digitales esenciales para proseguir la entrega de sus mensajes en compañía de su guitarra-.

No se puede desmerecer la validez propia que pueda tener la interpretación de un lector desconocedor de la historia y sociedad chilena, ya que la lectura y su entendimiento llevan a una experiencia íntima y única; sin embargo, espero que estas páginas sean un acicate para aquellos lectores foráneos — como aquellos chilenos que por diversas razones puedan desconocer ciertas páginas de la vida de la nación chilena 
que tan afablemente ha abierto Isabel Allende para sus lectores- que han despertado un interés integral en la literatura hispanoamericana y más específicamente, chilena.

$\mathrm{Al}$ aferrarnos a las premisas de la hermenéutica podremos profundizar e indagar, e inclusive, llegar a percibir los fuelles que impulsaron a la autora a despojarse de remembranzas, zozobras y momentos de júbilo impresos en el texto para que pudieran llegar a nosotros: los receptores de su intención y mensaje.

Y concluyo esta sección sobre hermenéutica con una breve cita del gran preceptor de esta disciplina, Hans-Georg Gadamer, en la cual evoca la relevancia del la historia para comprender las implicancias del presente así como de una realidad determinada (sea ésta textual o no): Understanding is bound and embedded in history. ${ }^{43}$ 


\section{CONCLUSION}

A través del presente proyecto he querido comprobar la evidencia lingüística que se encuentra impresa en La casa de los espíritus que demarca el medio ambiente dentro del cual se desenvuelven los personajes y sus respectivas acciones por medio de la palabra. Al igual que al prestar atención a la situación geográfica y espacial, también nos damos cuenta que todas las descripciones e indicios expuestos en la obra, apuntan a la nación chilena donde creciera Isabel Allende y cursara sus estudios primarios y humanistas. Nuevamente, resulta práctico el remontarse a los cimientos de los componentes de la obra literaria, como los son la forma y el contenido. Al aludir a estos aspectos pilares de cualquier creación literaria, he querido demostrar con forma -a través del presente estudio- aquellos términos característicos y comunes pertenecientes al castellano hablado en Chile (incluyendo araucanismos, quichuísmos, lunfardismos, y/o -en general- americanismos), todo lo cual demarca sutilmente la isoglosa o comunidad lingüística en la que se proyectan los personajes de la obra.

Con respecto al contenido, vale la pena relacionarlo con dos aspectos peculiares. El primero se refiere a los parajes y descripciones geográficas que demuestran que el emisor conoce y se refiere a las bondades edénicas, que se han otorgado a un país tan remoto y aislado como lo es Chile. $\mathrm{Y}$, finalmente, el conjunto de personajes que conforman La casa... simboliza fehacientemente las personalidades que —de un modo 
u otro- estuvieron ligadas y presenciaron la caída de Allende, y los sufrimientos y torturas bajo el régimen de Augusto Pinochet.

Al fusionar estos dos elementos basales, forma y contenido, éstos conllevan otra función por ejecutar: ¿cómo emplearlos e intepretarlos conjuntamente? En este caso, el filósofo, Hans-Georg Gadamer, nos brinda ciertas aseveraciones que nos podrán guíar para acercarnos a una respuesta a la mencionada interrogante y así también acercarnos a las premisas de la hermenéutica. He aquí algunas conclusiones célebres a las cuales ha llegado Gadamer, que se relacionan directamente con los fundamentos de la hermenéutica: (1) el comprender implica poder interpretar; (2) todo entendimiento está ligado de manera esencial con el lenguaje; y (3) la comprensión del significado no puede separarse del uso de éste (Hugh J. Silverman 6).

El concepto de la hermenéutica literaria afirma que la interpretación de la obra está vinculada con la intención original de la autora, cuyo propósito y mensaje están estrechamente arraigados al pasado y el vivir de ella, como un fiel reflejo de sus propias percepciones; tal como lo indica la misma Isabel Allende en su obra autobiográfica, Paula :

El 8 de enero [1981] llamaron por teléfono de Santiago anunciando que mi abuelo estaba muy enfermo y esa noticia... me lanzó en una dirección muy inesperada. El Tata iba para los cien años, estaba convertido en un esqueleto de pájaro, semiinválido y triste, pero perfectamente lícido. 
Cuando terminó de leer la última letra de la Enciclopedia Británica y aprenderse de memoria el Diccionario de la Real Academia..., comprendió que era hora de morirse y quiso hacerlo con dignidad..., invocando al fantasma de mi abuela para que lo ayudara en ese trance, en vista de que su nieta le había fallado de tal mala manera... Decidí escribirle por última vez... Para probarlo empecé la carta con una anécdota de mi tía-abuela Rosa, su primera novia, una joven de una belleza casi sobrenatural, muerta en misteriosas circunstancias poco antes de casarse, envenenada por error o maldad... (303)

Y, para detener la hilvanación de mis líneas aquí impresas, quisiera concluir con una última cita tomada de la obra titulada Interviews With Latin American Writers de MarieLize Gazarian G., en donde Isabel Allende dice: Almost all my characters are based on real-life people... There is a part of my biography in The House of the Spirits and Of Love and Shadows (Gazarian 19) ${ }^{44}$. Por lo tanto, nos podemos percatar que son estos aspectos del pasado de la autora los que conforman y se manifiestan tácitamente en la obra, y los que —según las premisas de la hermenéutica - deberíamos llegar a vislumbrar y esclarecer a través de la asimilación de la lectura de La casa....

Por otra parte, resulta apropiado remarcar el hecho que los americanismos presentes en la obra son de una cantidad considerable, y que su presencia también revela 
muchos indicios socio-culturales pertinentes a la obra. Se observó que para mis informantes españoles, resultó imposible reconocer los términos provenientes del mapudungún y el quichua al no tener previa exposición o preparación en estas lenguas - lo que resulta muy lógico y fácil de entender, ya que estas voces no se utilizan en España y más bien podrían ser consideradas como acuñaciones desconocidas. De la misma manera, la muestra del legado lexicológico de estos dos pueblos precolombinos (mapuches e incas), también, resultaron ser una barrera para los informantes de Mesoamérica. Igualmente ocurriría si se examinara la competencia que pudieran tener los sudamericanos de los ricos giros y voces, por ejemplo, del náhuatl. De una forma u otra, estos resultados se podrían también anticipar hasta cierto grado.

En cuanto al vocabulario pasivo, los resultados mostraron ser relativamente análogos sin importar el punto de origen del informante. Para el reconocimiento de pasajes, fue notorio que aquel informante con cierto conocimiento de Chile supiera ambientarse al medio circundante, mezclándolo con el contenido de la obra. Pero los hubo aquéllos que simplemente recurrieron a su realidad inmediata para asimilar los pasajes con su acontecer diario. $\mathrm{Y}$, finalmente, cabe señalar cuán fieles fueron las respuestas de algunos informantes no provenientes de Chile, que debido a su preparación, conocimiento general y, en otros casos, debido a su permanencia en Chile, demostraron sólidos fundamentos sobre el tema. 
Finalmente, quisiera hacer una acotación referente al hecho de que gracias a la accesible literatura en español y los medios de telecomunicación del presente, uno se puede percatar sin mayor dificultad que la lengua española está cobrando un realce dinámico e internacional así como también una cohesión emergente entre las mismas naciones de habla hispana, en donde la comunicación entre un habitante de las tundras patagónicas con un veracruzano — por ejemplo— que esté disfrutando de las bondades de un clima tropical, sea expedita y funcional. Todos estos intercambios ayudarán a difundir el aporte y legado cultural que cada uno de nuestros pueblos ha recibido de las diversas culturas indígenas y hemos estado poco a poco creciendo como miembros de un mundo sin fronteras para el entendimiento y el intercambio. Así, todo intercambio cultural, y conocimiento más profundo de nuestra lengua como de nuestras realidades irán en beneficio de la proyección de América Latina, que se complementará y acrecentará al asociarse o contactarse con otros pueblos. El mejoramiento de la difusión de la literatura, además, nos permitirá estar a la par con aquellos acontecimientos ocurridos en el pasado, y aprender de nuestros pueblos hermanos para luchar en unisón por la comprensión y valorización de cada pueblo como un ente cultural y único. 


\section{NOTAS}

${ }^{1} \mathrm{El}$ nivel educativo de los informantes fluctúa desde profesores de la lengua hasta técnico-profesionales de otros rubros. De esa manera, se puede establecer que todos poseen una educación con un mínimo de dos años de educación superior o universitaria, o bien su equivalente (vale decir, desempeño laboral).

${ }^{2}$ Con el término "conocedor" me refiero a la persona que presenta una competencia literaria en cuanto a la vida socio-política de Chile. Bien se ilustra lo anterior con una de mis informantes estadounidenses, Emily Polanshek-Glick, quien experimentó la proyección y advenimiento del golpe de estado en carne propia. Y, así, se demuestra que el mensaje de Isabel Allende requiere que el lector tenga un cierto conocimiento de Chile. Irónicamente, esto limita también — hipotéticamente- a algunos chilenos, que viven en Chile y que - por el factor edad- no han llegado a comprender la realidad histórico-política del país.

${ }^{3}$ Esto se podría yuxtaponer y comparar a los sucesos específicos ocurridos entre 197073 en Chile.

${ }^{4}$ De aquí en adelante, la obra de Isabel Allende se abreviará, La casa...

${ }^{5}$ Is There Such a Thing as Latin American Literature? by World Views, with Isabel Allende, Willamette University Media Center, 1992 (1 video). Nótese que la abreviación L.A. Lit. se usará en adelante para referirse a esta referencia videográfica.

${ }^{6}$ Por "competencia" se implica la habilidad y destreza de codificar y decodificar un mensaje o enunciado pragmáticamente, es decir, la intención del emisor es asimilada funcional, 
correcta y naturalmente por el receptor, ya que ambas entidades comparten similares patrones referenciales e indexicales.

${ }^{7}$ Así como lo son para la lengua inglesa The British Broadcasting Corporation (BBC), o en los Estados Unidos, The Voice of America o Public Broadcasting Service (PBS).

${ }^{8}$ Como se indicará más adelante en este trabajo, la opción 'castellano' —para referirse a la lengua española - es de usanza en varios países de América Latina, especialmente en el Cono Sur de Sudamérica; en algunos otros países se usa tanto 'castellano' como 'español'; y finalmente en algunos sólo 'español' como es en el caso de México y, por extensión, algunas otras naciones de Mesoamérica.

${ }^{9}$ Nótese que se ha querido conservar la ortografía más próxima a la original al nombre de la lengua de los incas, ya que la vocal 'e' no existe en el idioma quichua; sólo le conforman las vocales: a-i-o-u (Montalvo 6).

${ }^{10}$ Mapudungún viene de 'mapu' que significa gente y 'dungún' que significa hablar, es decir, es la lengua del pueblo mapuche, lo que se conoce mejor en el vernáculo como simplemente 'mapuche' o 'araucano.'

${ }^{11}$ Fueguinos es la expresión con la que se denomina a los siguientes pueblos indígenas australes de Chile: cuncos, chonos, alacalufes, yaganes, tehuelches y onas (Torechio 70).

${ }^{12}$ El modo de articulación de 'ch' pueda determinar el origen, ya sea, rural o urbano del hablante, aparte de otras implicancias socio-lingüísticas. Cabe señalar que a través de los prominentes grupos de peregrinos franceses como provenzales que recorrían las vías románicas, siguiendo la ruta de Santiago de Compostela (en Galicia), "ch” se incorporó 
paulatinamente al grafemario del castellano; y aunque se intente su bifurcación alofónica libre y/o histórica, su fonema norma permanecerá como un sonido africado, es decir, $/ \mathrm{t}$ / (Alatorre $98,109-11)$.

${ }^{13}$ Otro fenómeno propio de las lenguas romances. Un caso representativo de la omisión de "s" ante consonante de manera gráfica ocurre en el francés, también, en ciertas palabras, en donde ha quedado sólo el acento circunflejo como remanente de tal grafema, e.g.: hospital $\Leftrightarrow$ hôpital; pasta $\Longleftrightarrow$ pâte.

${ }^{14}$ También un caso típico del romance. Un buen ejemplo se ilustra con la palabra "feo" tomada del latín clásico fcedus (DRAE 959) en donde la "d" intervocálica simplemente no se ha conservado en el castellano norma actual.

${ }^{15}$ Es sólo una aproximación del símbolo fonético correspondiente al sonido original de "ll" o /ly/.

${ }^{16}$ La zona transandina, mejor dicho, la Provincia de Cuyo (i.e., Mendoza y San Juan) fue poblada desde sus orígenes desde Chile, ya que ésta perteneció a la Capitanía de Chile por casi 2 siglos (del XVI al XVIII, aproximadamente). Por ello, se puede apreciar cierto grado de similitudes entre el habla de Chile y el de esta región, aunque el modelo porteño sigue vigente como modelo lingüístico en toda Argentina (Lipski, Latin American Spanish 162-5).

${ }^{17}$ Así, resulta muy común el oír palabras como "kuchen" (tarta), "garzón del francés, garçon" (mozo), "surmenage" (stress: estrés), "chao" o "ciao" (adiós). 
${ }^{18}$ Chile se separa al Norte del Perú y al Noreste Bolivia por el Desierto de Atacama (uno de los desiertos más áridos del mundo); al Este, por la Cordillera de los Andes que bifurca a Chile y Argentina; al Sur, el país se desmiembra en numerosos archipiélagos e islotes en donde reinan hábitats y hielos que han perdurado por centurias, extendiéndose hasta llegar al Continente Blanco; y al Oeste, las aguas del Pacífico bañan su luengo litoral.

${ }^{19}$ El currículum del sistema de educación de Chile fue —originalmente- una copia de elementos tomados del currículum alemán, francés y belga (Bizzarro 169-171). Cabe mencionar, además, que la influencia de la estandarización del castellano hablado en Chile por Andrés Bello, tuvo un rol primordial en la educación y habla chilena.(Torrejón 65-71).

${ }^{20}$ Los arcaísmos implican el empleo de voces, frases o maneras de decir anticuadas, y sólo vigentes y de uso cotidiano en regiones que por razones históricas y/o geográficas han estado aisladas y distanciadas del flujo lingüístico de los otros centros prominentes de la lengua, en donde ya se ha adoptado un substituto o sinónimo para ciertas palabras.

${ }^{21}$ Se debe destacar el hecho de que en Chile se tiene dos versiones que explican el origen de esta singular frase cotidiana. La primera se refiere al código secreto que tenían los hombres en el pasado para tomar un receso de sus actividades y disfrutar un trago de aguardiente; de ahí se cree que viene la frase "once", es decir, de las once letras que componen la palabra 'aguardiente'. La segunda explicación y que se acerca más a lo que representa esta ocasión social, se remonta a la lejana Inglaterra, donde es consuetudinario el "tomar las onces" o más precisamente "to have elevenses" (entre el desayuno y el almuerzo-alrededor de las 11 horas - valga la redundancia-), lo que consiste - al igual que en la actualidad en Chile, a 
diferencia de su hora- de una pequeña merienda compuesta por té, tradicionalmente, acompañado de panecillos con queso, mermelada y otros (comentario personal). Torechio, por otra parte, destaca el hecho de que la costumbre de tomar té en Chile se arraigó a través de Lady Catherine Cochrane quien al incorporarse a la alta sociedad chilena, dejó este hábito tan típico de Inglaterra y del Asia. Torechio, además, señala que "el té se usó en Chile desde 1795 como sudorífico; pero desde 1818 Lady Catherine Cochrane lo puso de moda, siendo inicialmente circunscrito a unas pocas casas aristocráticas inglesas" (169).

22 Cabe señalar que el filólogo mexicano, Moreno, indica - de acuerdo a Dámaso Alonso- que los neologismos —ya desde aproximadamente 1930 en adelante- han sido adoptados vía Norteamérica, exclusivamente (91).

${ }^{23}$ Desde ahora en adelante, me refiriré al Diccionario de Americanismos Sopena con la abreviación DAS.

${ }^{24}$ El DRAE indica que la palabra "lacho" se utiliza en Chile, denotando a un "amante, galán; hombre enamoradizo."

${ }^{25}$ Gusarapo: cualquiera de los animalejos, de forma de gusanos, que se crían en los líquidos (DRAE).

${ }^{26}$ Sin embargo, según mis informantes, esta expresión se emplea en otras naciones latinoamericanas también. 
${ }^{27}$ Cabe señalar que en las encuentas que he realizado con algunos de mis informantes, me han dado a entender que la expresión "hacer y/o pagar mandas" también es válida para otras naciones de la América Latina, como lo es México —entre otros.

${ }^{28}$ Del griego lexis: palabra y lexikon: libro (compárese con biblion) .

${ }^{29}$ Estas acuñaciones, por lo general, surgen en los países angloparlantes, que a su vez tienen la tendencia de seleccionar y establecer términos o al menos raíces para estos nominales provenientes del latín o el griego, haciendo estos términos y acuñaciones de fácil reconocimiento y adoptación, en general, por la mayor parte de las lenguas contemporáneas.

${ }^{30}$ Aparte de la parte meridional de Colombia, que también recibió influencia de los incas.

${ }^{31}$ Las siguientes definiciones son meras adaptaciones mías, obtenidas originalmente del Pequeño Larousse 1996.

${ }^{32}$ Según Isabel Allende, sólo es su madre quien revisa la ortografía, dicción y redacción de sus manuscritos (Gazarian 19-20).

${ }^{33}$ No quiero contradecir el postulado de Noam Chomsky, pero la denotación lingüística (de competencia —como estrictamente el conocimiento sobre un idioma-) que expone en su tratado de Competence and Performance no es pertinente a este estudio, ya que a lo que me refiero yo con 'competencia' es al conocimiento y a la facilidad de poder interpretar cierta situación o interacción sociolingüística, pudiendo percibir y asimilar el contenido y su respectivo mensaje gracias a la información que se ha adquirido previamente. 
${ }^{34}$ Para ratificar y profundizar mis referencias y respuestas a estas citas, se recomienda consultar los siguientes autores: Alegría, Bizzarro, Torechio, y Valenzuela (J. S.); y las siguientes grabaciones de video: Chile: A Rough Guide by BBC; y Chile in Women's Hands by PBS.

35 Viene al caso citar que Blanca dice que... Miraba al cielo...., con la esperanza de que alguna vez cayera una gota de lluvia que aliviara la oprimente aspereza de ese valle lunar (La casa... 241) Y, el Valle de la Luna... (ubicado en las cercanías de Calama en la II Región del país) consiste en "formaciones salinas de la Sierra Barros Arana [que] han dado origen a un peculiar paisaje esculpido por el viento y el sol, que cambia de tonalidad a lo largo del día" (Edit. Antártica 62).

${ }^{36}$ Cuya organización de debió al Padre alemán de quien Blanca hace mención en página 242. "San Pedro de Atacama [a $100 \mathrm{~km}$. de Calama] se hizo mundialmente conocido gracias a los descubrimientos arqueológicos del Padre Le Paige. En este pueblo se encuentra el Museo Arqueológico más rico y variado de todo el norte chileno. Debido a la sequedad atmosférica se conservan en buen estado los restos humanos momificados" (Edit. Antártica 64).

37 Adjetival que seleccionó Isabel Allende para calificar los bigotes del Dicatador, que coicide obviamente con el nombre de pila de Pinochet. Además, vale la pena señalar que el DRAE define "augusto" de la siguiente manera: "Dícese de lo que infunde o merece respeto y veneración por majestad y excelencia.ll Título de Octaviano César, que llevaron después todos los emperadores romanos y sus mujeres.ll Payaso de circo. 
Oregon Public Broadcasting. Americas: Chile in Women's Hands por WGBH Boston, 1993.

${ }^{39}$ Compárese la contraparte romana, Mercurio.

40 Referiéndome —en este caso particular- a Isabel Allende.

41 Traducción mía para "reception theory".

42 Rees, Earl. "La literatura de denuncia y escritores engagés". Literatura Hispanoamericana. Portland State University, Oregon, Spring 1993.

${ }^{43}$ "El entendimiento se encuentra ligado e incrustado en el pasado" (traducción mía).

44 "Casi todos mis personajes están inspirados en personas de la vida real... Una parte de mi biografía se encuentra tanto en La casa de los espíritus como en De amor y sombra" (traducción mía). 


\section{BIBLIOGRAFIA}

Abrams, M.H. A Glossary of Literary Terms. Fort Worth, Tx.: Harcourt Brace, 1988.

Alatorre, Antonio. Los 1,001 años de la lengua española. México, D.F.: Fondo de Cultura Económica, 1993.

Alegría, Fernando. Allende: A Novel. Trans., Frank Janney. Stanford: Stanford UP, 1993.

- Allende: mi vecino. Santiago: Editorial Planeta Chilena, 1990.

-Is There Such A Thing As Latin American Literature? [L.A. Lit.] Atkinson Lectures. Willamette University, Salem, Oregon. Oct. 1992.

__ La casa de los espíritus. [La casa...] Barcelona: Plaza \& Janés, 1992.

—. Paula. New York: Harper, 1994.

Americas: Chile In Women's Hands. OPB, by WGBH-Boston, 1993. (video series)

Americanismos [DAS]. Barcelona: Casa Editorial Sopena, 1982.

Babson, Jane. The House of the Spirits . World Views Lectures. Willamette University, Salem, Oregon. Oct. 1992.

Becker, Luisa et al. Gran libro de la cocina chilena. Santigo de Chile: Editorial Bibliográfica, 1993.

Bizzarro, Salvatore. Historical Dictionary of Chile. New Jersey: The Scarecrow Press, Inc., 1987.

Bizzell, Patricia \& Bruce Herzberg. The Rhetorical Tradition. Boston: Bedford Books of St. Martin's Press, 1990.

Chavkin, Samuel. The Murder of Chile. New York: The Everest House, 1982.

Chile: A Rough Guide. PBS, by BBC, 1993. (1 video)

Corominas, Joan \& José A. Pascual. Diccionario crítico etimológico castellano e hispánico (Vols. I-VII). Madrid: Editorial Gredos, 1991. 
Cuddon, J.A. Dictionary of Literary Terms \& Literary Theory. London: Penguin Books, 1991.

De Augusta, Félix José. Diccionario español-mapuche (Tomo II). Santiago de Chile: Ediciones Séneca, 1991.

Ducrot, Oswald \& Tzvetan Todorov. Trans., Catherine Porter. Encyclopedic Dictionary of the Sciences of Language. Baltimore: The Johns Hopkins UP, 1987.

Eagleton, Terry. Literary Theory. Minneapolis: U of Minnesota P, 1991.

El Pequeño Larousse 1996: Diccionario Enciclopédico. Massachusetts: Larousse, 1995.

Editorial Antártica. Chile a color, geografia. Santiago de Chile: Biblioteca Antártica, 1983.

Gazarian Gautier, Marie-Lise. Interviews With Latin American Writers. Illinois: Dalkey Archive Press, 1992.

Grass, Jacobo. Diccionario de chilenismos. Santiago de Chile: Editorial Pax, 1993.

Green, Georgia M. Pragmatics and Natural Language Understanding. Hillsdale, New Jersey: Lawrence Erlbaum Associates, Inc., 1989.

"Groliers". The 1995 Multimedia Encyclopedia. CD-ROM.

Hart, Patricia. Narrative Magic In The Fiction Of Isabel Allende. Cranbury, New Jersey: Associated UP, 1989.

Henfrey, Colin \& Bernardo Sorj. Chilean Voices. London: The Harvester Press Limited, 1977.

Hudson, Rex A. et al. Chile: A Country Study. [Ch. II: "The Society and Its Environment" by J. Samuel Valenzuela]. Washington, D.C.: Library of Congress, 1994.

Lázaro Carreter, Fernando. Diccionario de términos filológicos. Madrid: Gredos, 1990. 
Lipski, John M. "Hispania 72". Beyond the Isogloss: Trends in Hispanic Dialectology. Dec. 1989.

- Latin American Spanish. [Chs. on Argentina, \& Chile] London: Longman, 1994.

Moreno de Alba, José. El español en América. México, D.F.: Fondo Cultural Económico, S.A., 1991.

Morínigo, Marcos A. Diccionario Manual de Americanismos. Buenos Aires: Muchnik Editores, 1966.

Noix (de la), P \& H. Lengua, lenguaje, comunicación. Limache, Chile: Editorial Claret, 1977.

Oroz Scheibe, Rodolfo. La lengua castellana en Chile. Santiago de Chile: Editorial Universitaria, 1966.

Ossadón, Carlos. Santiago Guide: City Walks In Santiago. Santiago de Chile: SERNATUR, 1983.

Patterson, William and Héctor Urrutibéheity. The Lexical Structure of Spanish. Paris: Mouton, 1975.

Pinochet Ugarte, Augusto. El día decisivo: 11 de septiembre de 1973. Santiago de Chile: Instituto Geográfico Militar de Chile, 1982.

—. The Crucial Day. Santiago de Chile: Editorial Renascimiento, 1982.

Real Academia Española. Diccionario de la Lengua Española (21a. ed). Madrid: Editorial Espasa Calpe, 1995.

Roa Bleck, Alejo. Gramática castellana. Santiago de Chile: Editorial Salesiana, 1991.

Romera Castillo, José. El comentario semiótico de textos. Madrid: Sociedad Española de Textos, 1980. 
Sigmund, Paul E. The Overthrow of Allende: and the Politics of Chile, 1964-1976. Pittsburgh: University of Pittsburg Press, 1976.

Silverman, Hugh J. Gadamer and Hermeneutics. New York: Routledge, 1991.

Sobel, Lester A. et al. (eds.). Chile \& Allende. New York: Facts on File, Inc., 1974.

Subercaseaux, Miguel. Diccionario de chilenismos. Santiago de Chile: Editorial Juvenil, 1992.

Sweet Country. Prod. \& dir. by Michael Cocoyannis. Playhouse Productions Inc., 1985.

The House of The Spirits. Dir. by Bille August. Miramax Films, 1993.

Torechio, Donato. Diccionario histórico y costumbrista de Chile. Santiago de Chile: Editorial Antártica, 1986.

Torrejón, Alfredo. Andrés Bello y la lengua culta: la estandarización del castellano en América en el siglo XIX. Boulder, Colorado: Society of Spanish and SpanishAmerican Studies, 1993.

Traugott, Elizabeth C. \& Mary L. Pratt. Linguistics for Students of Literature. San Diego: Harcourt Brace, 1989.

Urrutia de Hazbun, Rosa \& Carlos Lanza Lazcano. Catástrofes en Chile: 1541-1992. Santiago de Chile: Editorial La Noria, 1993.

Valenzuela, Arturo \& J. Samuel Valenzuela. Chile: Politics and Society. New Brunswick, New Jersey: Transaction Books, 1976.

Valenzuela, J. Samuel \& Arturo Valenzuela. Chile and the Breakdown of Democracy. Boston: Cambridge P, 1982.

Zamora Vicente, Alonso. Dialectología española. Madrid: Editorial Gredos, S.A., 1967. 
A NEXOS 
I N D I C E

I. Manifestaciones (típicamente chilenas):_____ 91

1. Arbóreas__ 92

2. Frutícolas__ 92

3. Hortícolas___ $\quad 92$

4. Florales___ 93

5. Culinarias___ 93

6. Ornitológicas___ 94

II. Arboles genealógicos___ 95

1. Las protagonistas (descendientes) de la flia. Trueba del Valle___ $\quad 95$

2. Descendientes de Pedro García (el Viejo)___ 95

3. Familia del Valle___ 96

4. Familia Trueba del Valle____ 96

5. Familia Trueba___ 96

$\begin{array}{ll}\text { III. Ilustraciones alusivas a la obra___ } & 97\end{array}$

1. Supuesta inspiración de la Hacienda Las Tres Marías____ $\quad 97$

2. Expresiones costumbristas varias de Chile____ 106

3. Notas explicativas___ 110 
I. Manifestaciones típicamente chilenas.

La intención de presentar estos elementos que prosiguen, es confirmar el hecho que Isabel Allende describe tanto implícita como explicitamente el medio ambiente geoclimático y costumbrista correspondiente a Chile.

Un factor que ratifica de manera crucial la situación geográfica de la obra, se refiere a las alusiones que se hacen al medio ambiente de la obra cuyo clima es mediterráneo. Al indagar en la Enciclopedia Grolier (CompuServe), por ejemplo, la frase "clima mediterráneo", se nos enseña que existen sólo 5 (cinco) puntos en el planeta que gozan de estas benignas condiciones atmosféricas, las cuales son: (1) California, (2) Chile Central; (3) el Cabo Occidental de Sudáfrica, (4) sectores de Australia, y naturalmente (5) los territorios que rodean y pertenecen al Mar Mediterráneo.

Otros indicios e indicaciones se centran en el hecho que el Conde de Satigny iba a desposar - finalmente - a una heredera sudamericana (La casa... 205), nos delimita fácilmente el espacio geográfico que representa a Chile. Además, son contados los países en América Latina que no conforman parte de regiones con climas tropicales (una excepción es Uruguay, pero éste se descarta ya que no tiene la variedad de climas ni la Cordillera de los Andes como parte de sus accidentes naturales, entre otros factores descriptivos). Además, con estos listados, quisiera hacer resaltar que varias especies fueron llevadas a Chile desde Europa (tales como el conejo y la liebre, las moras, los eucaliptos [y éstos árboles a la vez de Australia], castaños, vid, etc); y como también se mencionan integrantes de la flora y fauna autóctona chilena y en otros casos, propia de Chile y Perú, tales como, las chinchillas, las llamas, perdizi [cojón]; las paltas, lúcumas, chirimoyas, papayas, tamarugo, papas.ii Y por último, cabe señalar que los ítemes de esta sección, son especies de la historia natural de Chile, resultando ser nombres de fácil 
reconocimiento como elementos constituyentes del diario vivir, incluyendo tales manjares como "la cazuela de ave" [o sopa de ave], leche asada, conejo en escabeche: manjares predilectos de muchos chilenos. e.g.: Manifestaciones:

1. Arbóreas:

- Alamos $(61,82)$

- Castaños (401)

- Cipreses (289)

- Encinos (172, 271)

- Espinos (309, 335)

- Eucaliptos $(62,383)$

- Mimbre (182)

- Nogales (172)

- Pinos (135, 196, 383)

- Tilos (32)

2. Frutícolas:

- Castañas (véase, castaño)

- Ciruelas (166, 167, 247)

- Damascos: (185)

- Duraznos (185)

- Fresas (293)

- Lúcumas (107)

- Manzanas (109, 243)

- Melón (60, 109)

- Naranjas: $(109,176)$

- Papaya: (206, 246)

- Paltas (325)

- Peras $(109,168)$

- Uvas $(52,293)$

3. Hortícola:

- Ajenjo (226) 
- Albahaca (185)

- Alcachofas (175)

- Alfalfa $(52,109)$

- Canela (60)

- Cilantro (337)

- Lentejas (163)

- Maíz (185)

- Manzanilla (12, 184, 185, 238)

- Maravilla $(52,109)$

- Mazorca (109)

- Papas $(168,239)$

- Perejil (255)

- Porotos $(23,360)$

- Trigo $(52,109,135,247)$

4. Florales:

- Camelias $(16,113)$

- Cardenales (145)

- Claveles (367)

- Dalias (90)

- Hortensias (147)

- Jazmín (96)

5. Culininariasiv:

- Cazuela de gallina (107)

- Conejo en escabeche (143)

- Dulce de membrillo $(23,84,163)$

- Empanadas (73, 353)

- Empolvados (206)

- Leche asada (281)

- Manjar blanco $(23,62,107)$

- Mermelada (185)

- Mil hojas (206)

- Torta de hojaldres (10) 


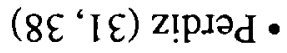

(29l) oมวnธิ|!! •

(ItI "6S) uoụnog •

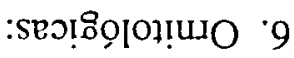


II. Arboles genealógicos:

1. Las protagonistas de la familia del Valle/Trueba del Valle.

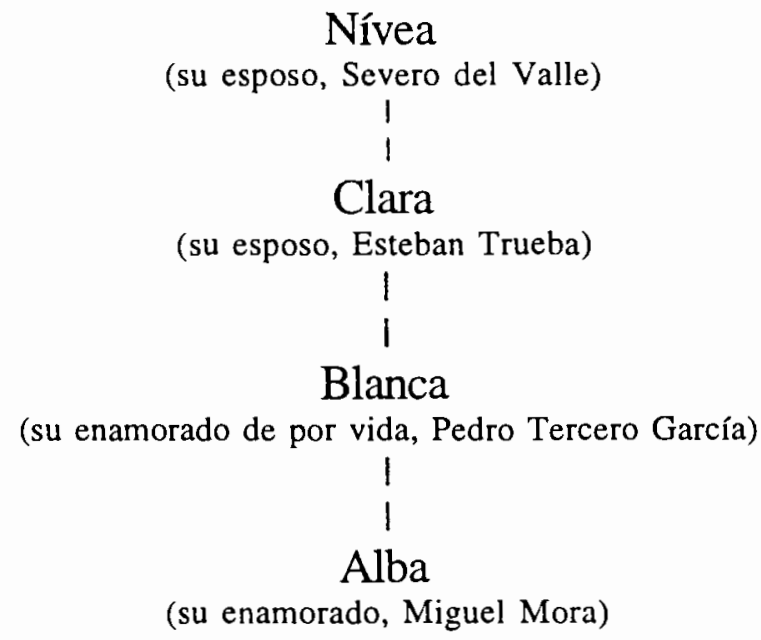

2. Los protagonistas principales de la familia García. (Nótese que este diagrama más bien ilustra las respectivas generaciones a las cuales pertenecen los miembros de la familia García).

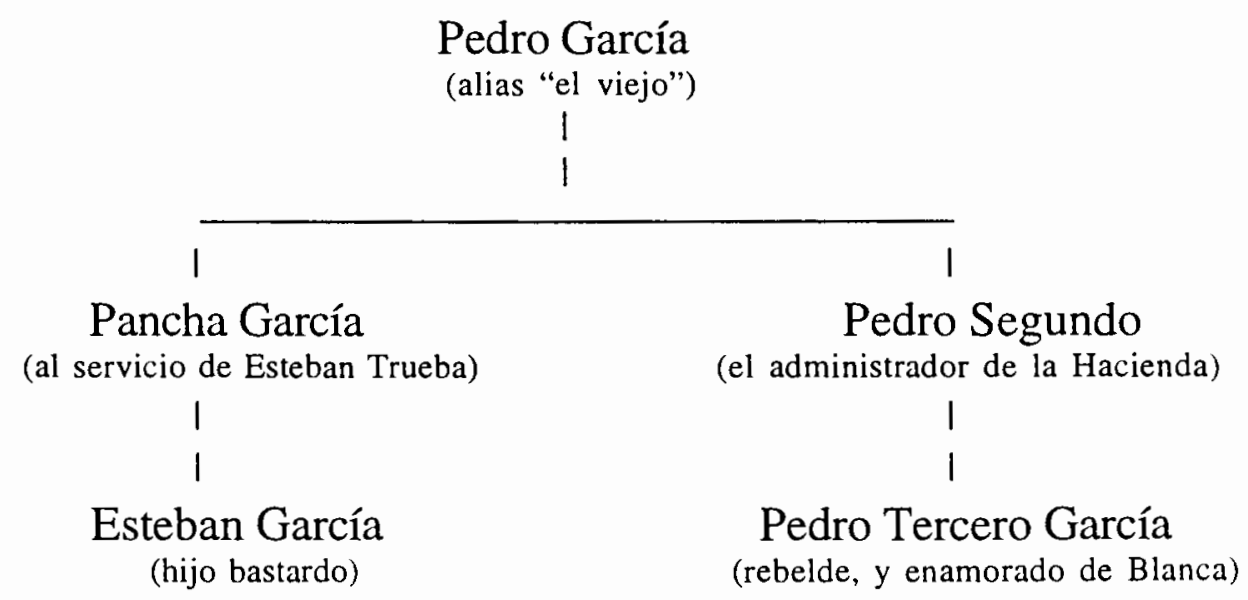


3. Familia del Valle.

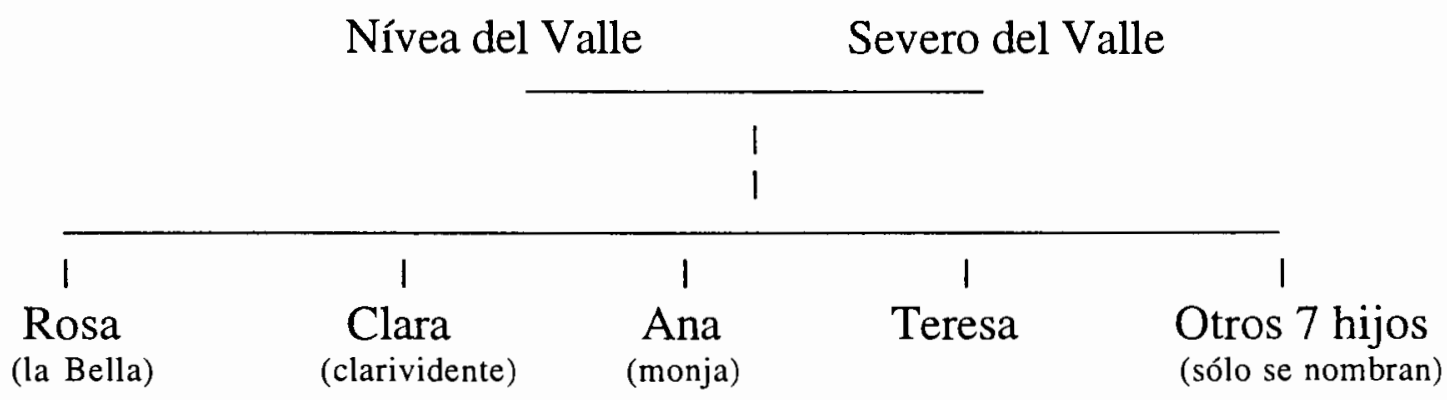

4. Familia Trueba del Valle.

Clara del Valle Esteban Trueba

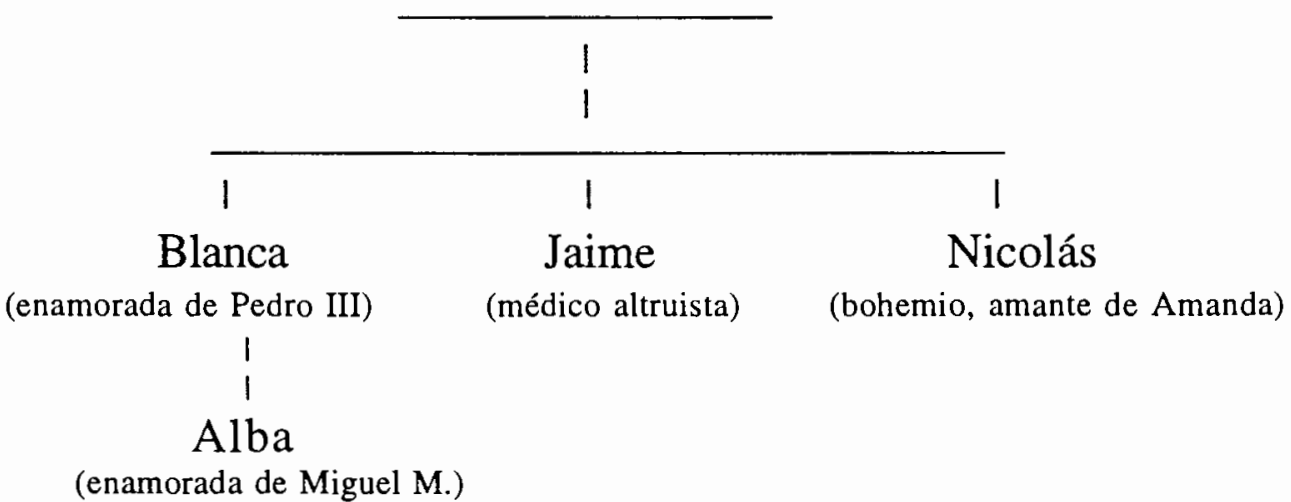

5. Familia Trueba.

\section{Ester}

(madre enferma)

i

1

Férula

(beata solterona)
Esteban

(emprendedor, machista) 
III. Ilustraciones alusivas a la obra.

1. Supuesta inspiración de la Hacienda Las Tres Marías (en fotografías).

En el mes de abril de 1995, Marlene E. A. Lagos M., colaboradora de esta tesis en Santa Bárbara-Chile, sostuvo una conversación/estrevista informal con el encargado de abrir los portales del Fundo Los Junquillos, hacienda ubicada en el centro-sur de Chile. El encargado de facilitar el acceso a este fundo para fotografiar esta hermosa residencia campestre sin dejar a duda su estilo influenciado por corrientes europeas, fue el sacerdote Mariano Puga, quien fuera nieto de un ex-embajador chileno en el Reino Unido, llevando el mismo nombre de éste. El jerarca (Mariano Puga, abuelo) de esta prominente familia dentro de la sociedad chilena, por alguna intrigante razón, decidió establecer su casa estival en esta remota localidad precordillerana, en donde las empinadas maravillas arquitectónicas del mundo urbano, no tienen cabida ni parangón con el colosal escenario que brindan picos y volcanes de la Cordillera de los Andes.

Para estimar las dimensiones de la residencia, sólo basta saber que cuenta con más de una docena de salas de baño adornados por mármol que define sus sobrios diseños. Esta zona es campestre, y seguramente se forjó con el esmero y labor de inquilinos. Con la posición holgada de esta antigua familia, prontamente la casona se fue adornando con fino mobiliario inglés, una excelente biblioteca que cubre una pared tras otra; en resumen, una infraestructura construida en un ambiente pastoril que obtuvo su aureola europea con todos los implementos que componen su interior: objetos y piezas 
de arte traídos de la Gran Bretaña u otras paradas durante la travesía de este embajador por el Viejo Continente. La relevancia de poner atención a este fundo y sus constituyentes, es que presenta muchas similitudes con la Hacienda Las Tres Marías, e inclusive su breve distancia a la Estación San Lucas o Santa Bárbara (pequeña comuna de unos 7 mil habitantes situada a aprox. 20 minutos de este fundo). Y como lo indica la obra de Allende, la distancia entre la capital (Santiago) y la Hacienda decreció con la construcción de la carretera, la cual implicaba un trayecto de sólo 6 horas, distancia que relativamente también se aproxima a la de este fundo. Sea esta la inspiración en la cual se basara Isabel Allende o no, este ambiente sirve para ilustrar la situación geográfica de un fundo exuberante rodeado de campesinos y apartado sólo por unos minutos a la próxima estación ferroviaria; cuya ubicación también coincide con el epicentro de 2 temblores temibles que padeció el Centro-Sur de Chilev.

Por otra parte, cabe destacar que Isabel Allende conformaba parte del círculo de amistades de la familia Puga. Dicha amistad acrecentó arraigadamente con las nefastas y atroces secuelas del Golpe Militar de 1973 en Chile. El padre Mariano Puga participó activamente, socorriendo a los más necesitados y tal vez recorriendo aquel Barrio de la Misericordia de la capital que menciona Isabel Allende, donde se destacaba y se destaca el sacerdote Puga por su labor austera y dedicada - tal como lo haría el padre José María —en la obra. (Basado en entrevista por Marlene E. Lagos al sacerdote Mariano Puga, Sta. Bárbara-Fundo Los Junquillos, VIII Región del Biobío, Chile, abril de 1995; y las fotografías son gentileza del Prof. Herman Sanhueza). 


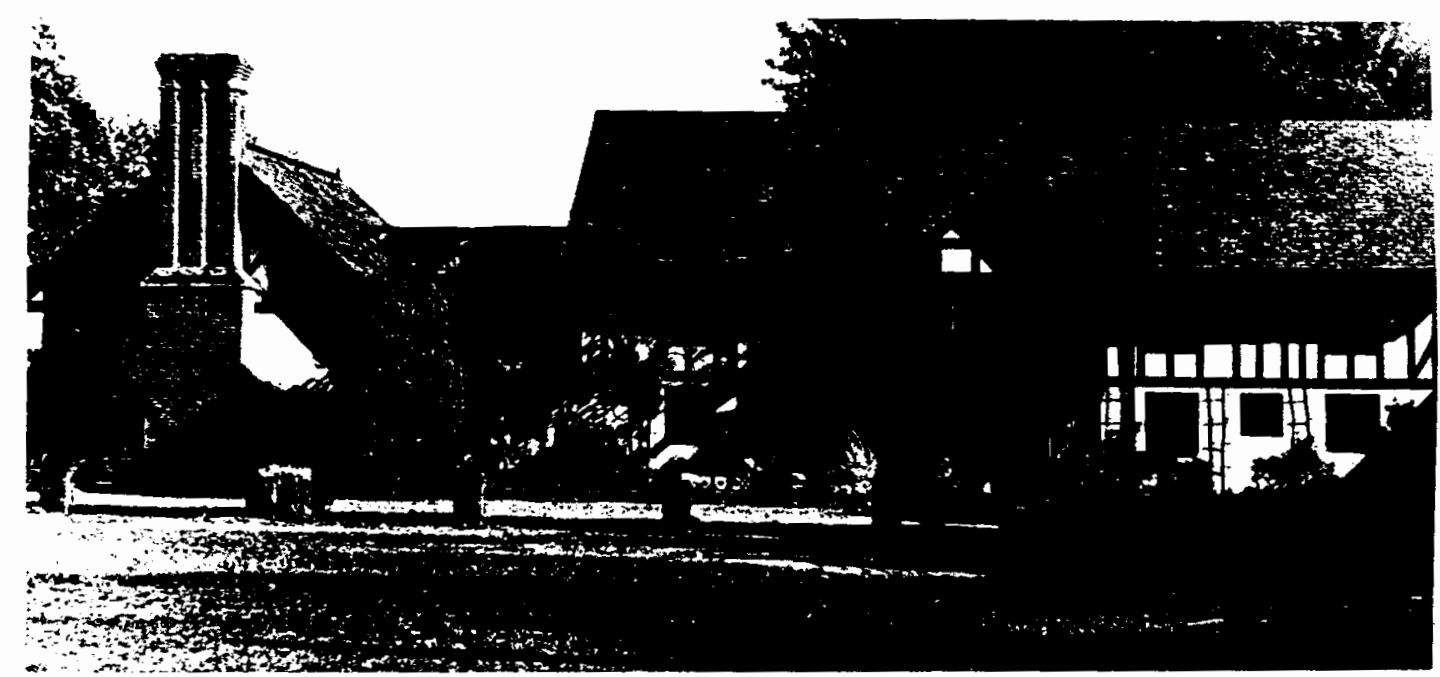

FOrO No. 1: Casona de verano de la flia. Puga, Fundo Los Junquilios.

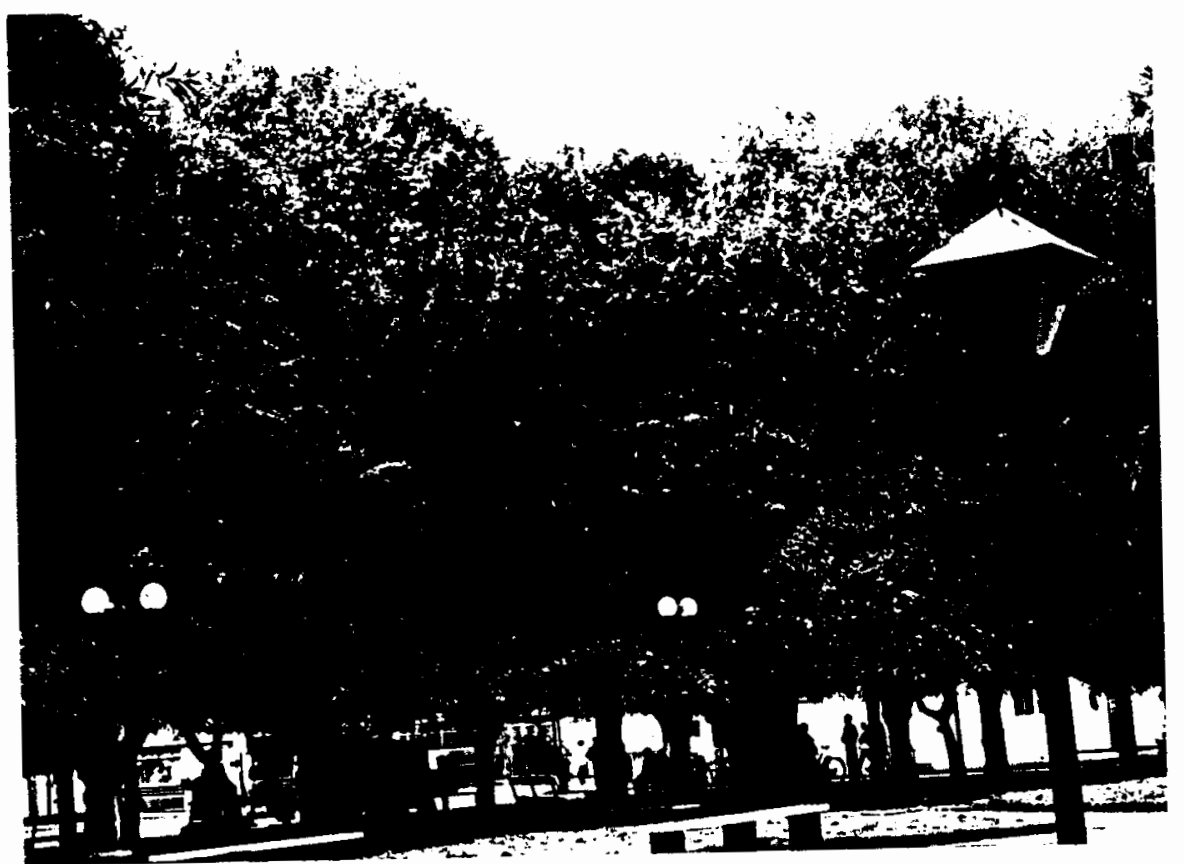

FOTO No. 2: Plaza Principal de Santa Bárbara, rodeada de tilos. 


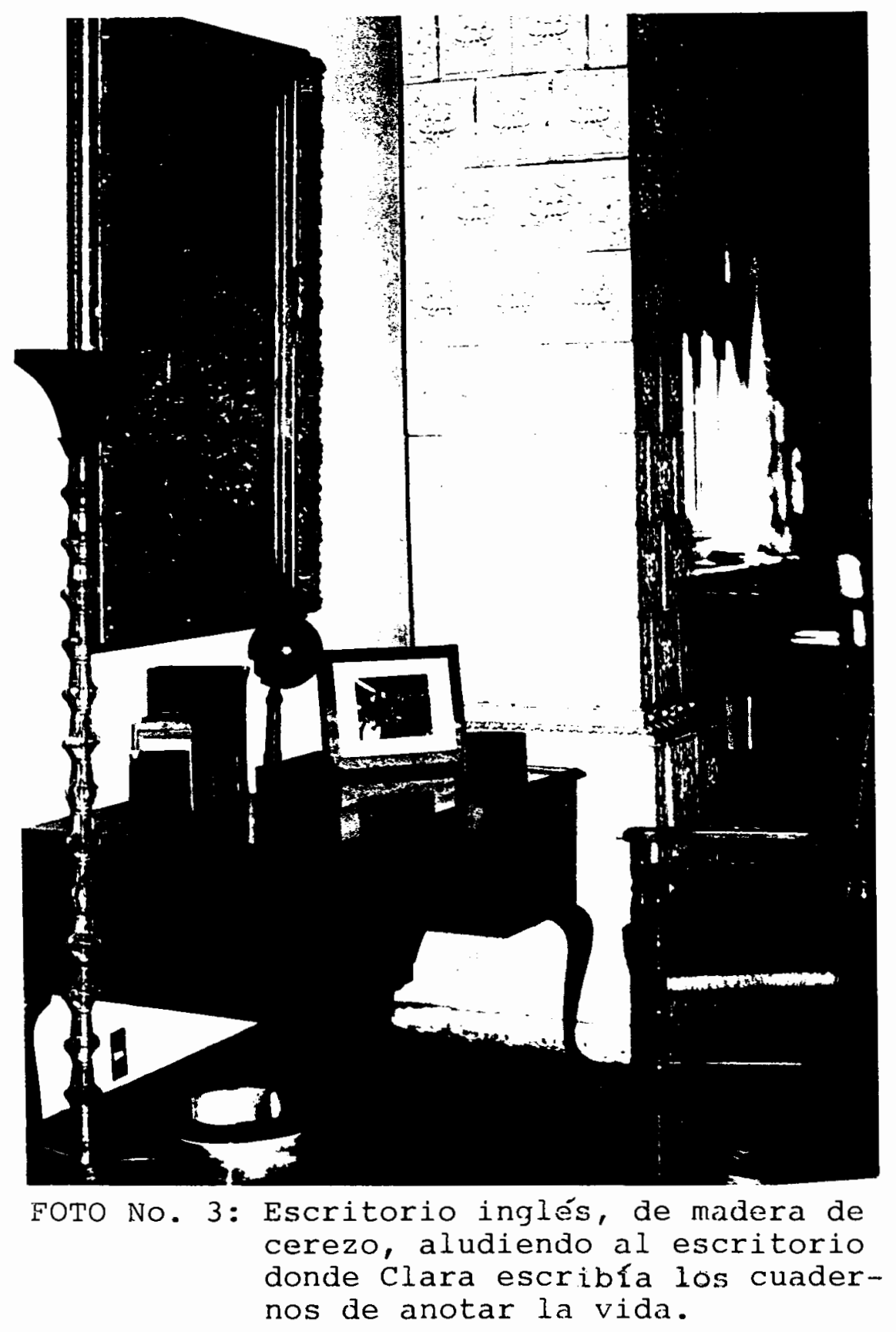




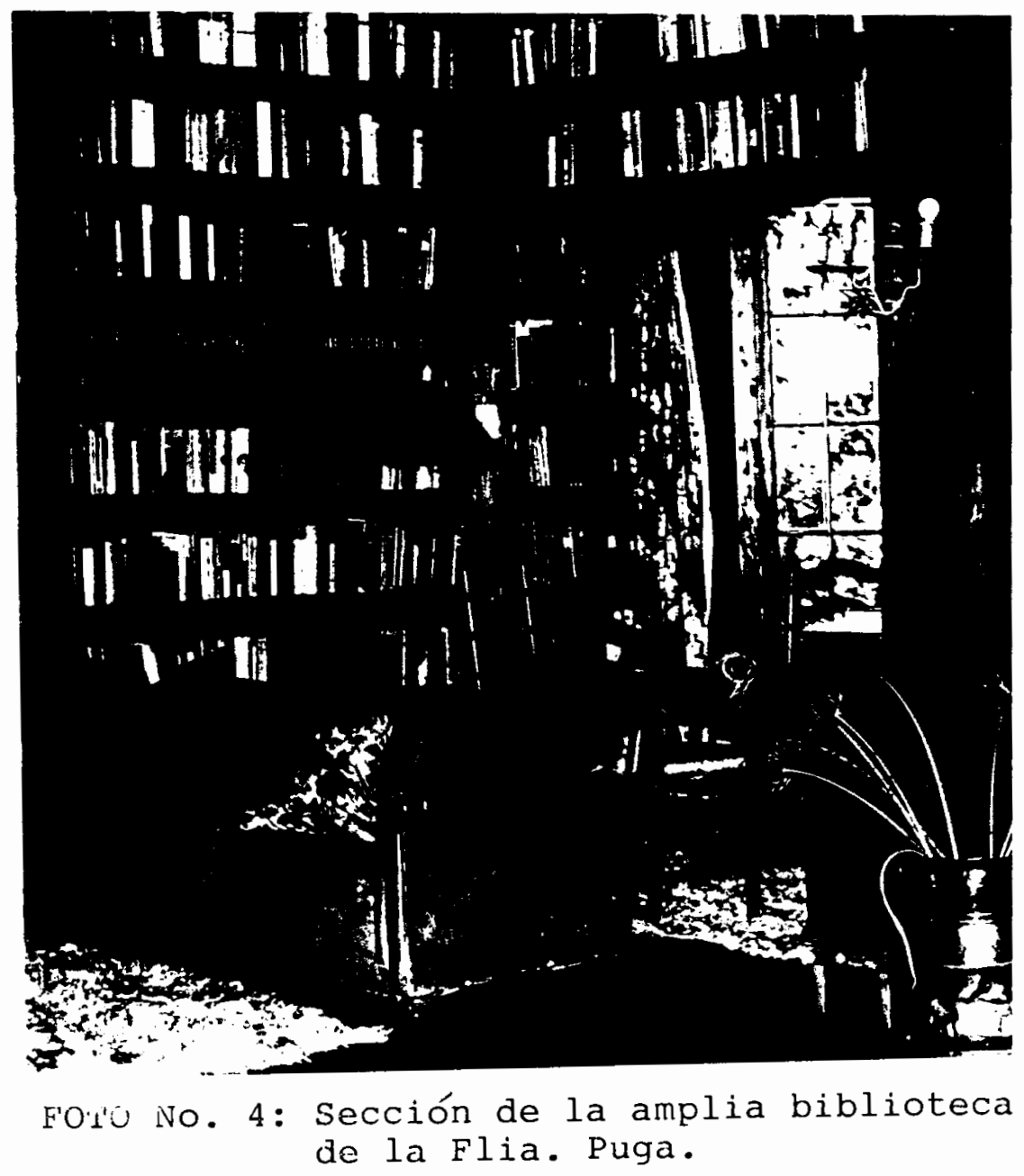




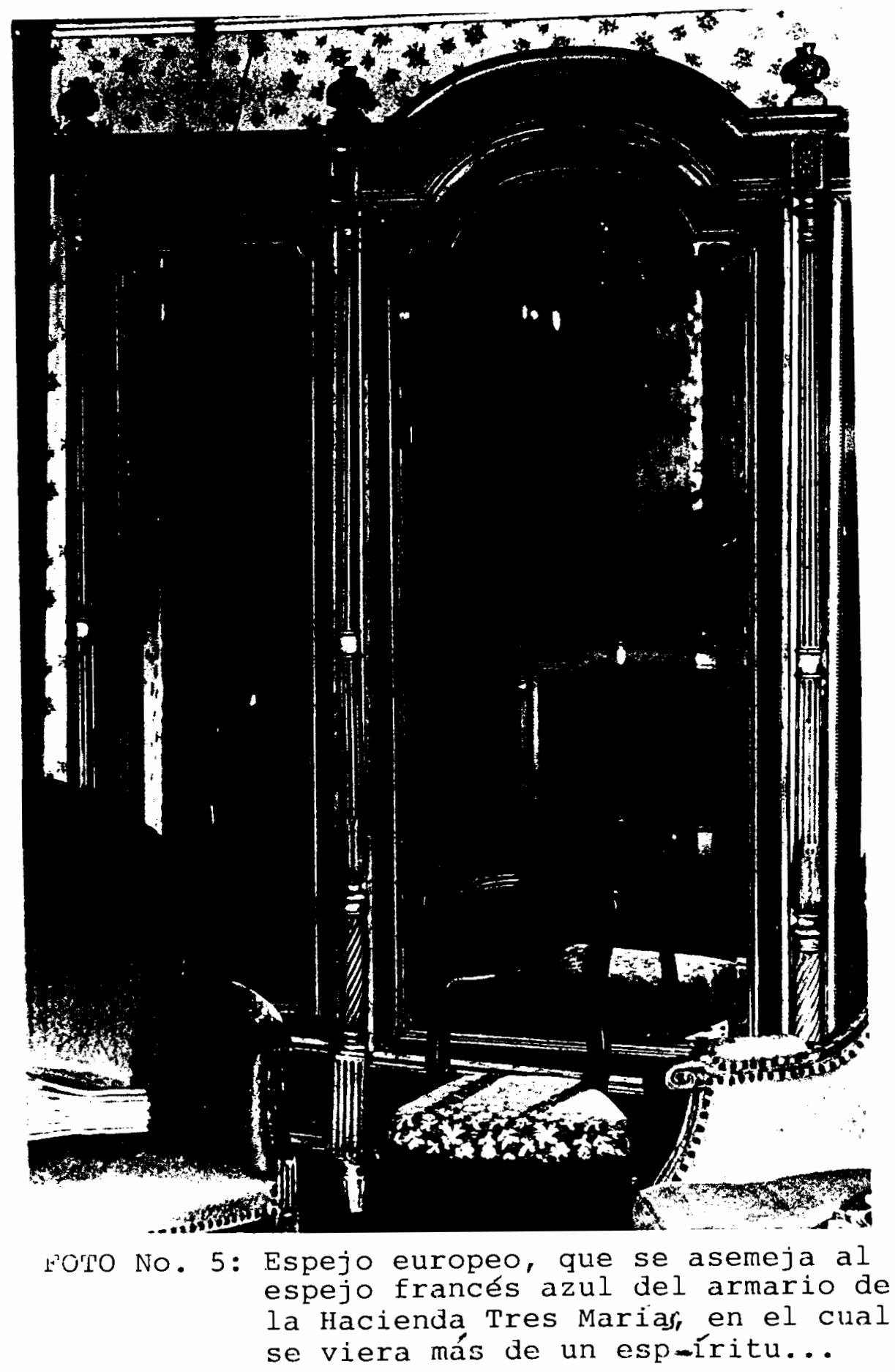




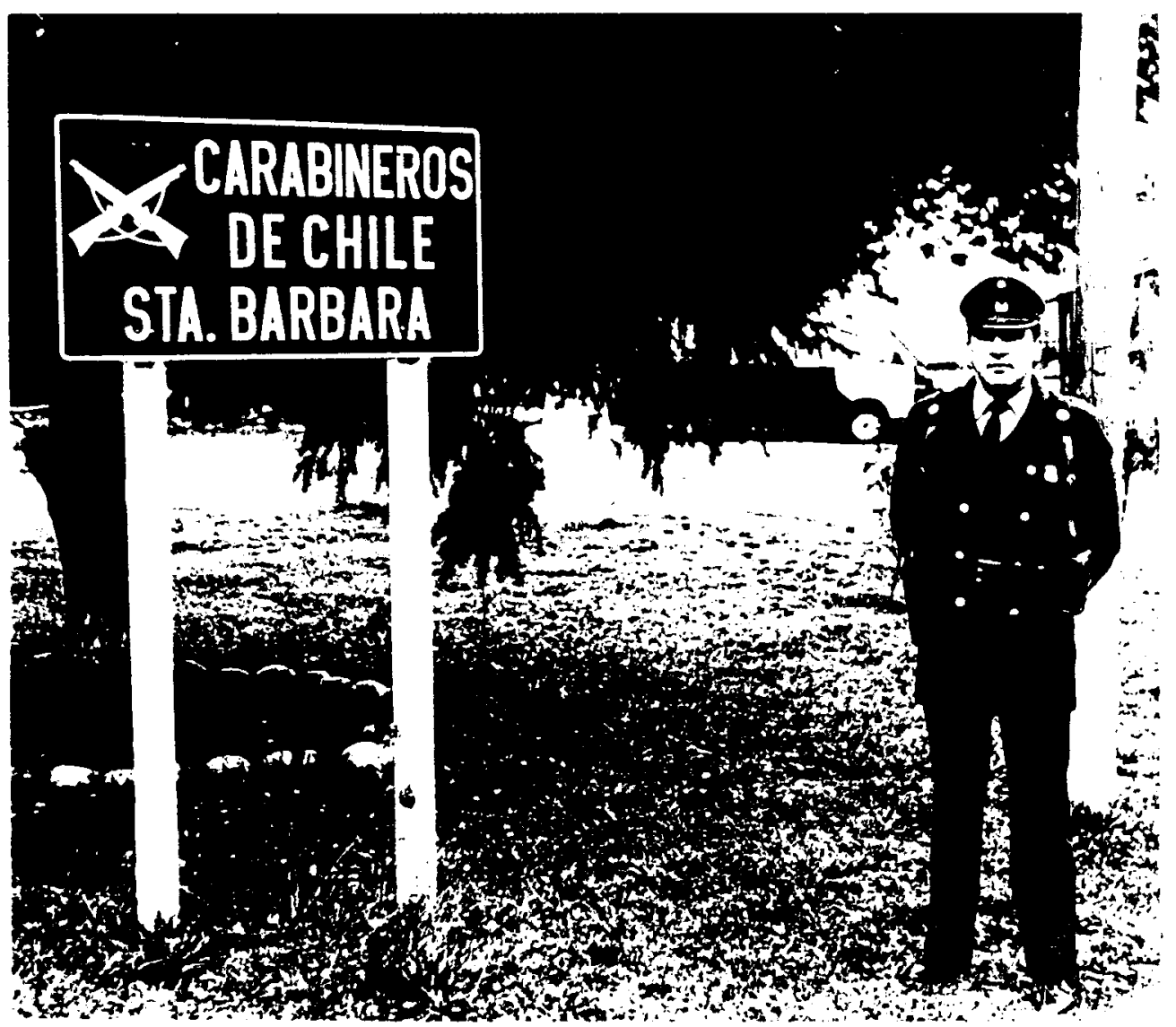

Foto No. 6: Tenencia de Carabineros de Santa Bärbará,
comunidad contigua al Fundo Ios Junquilíos. (Cabo Chávez). 


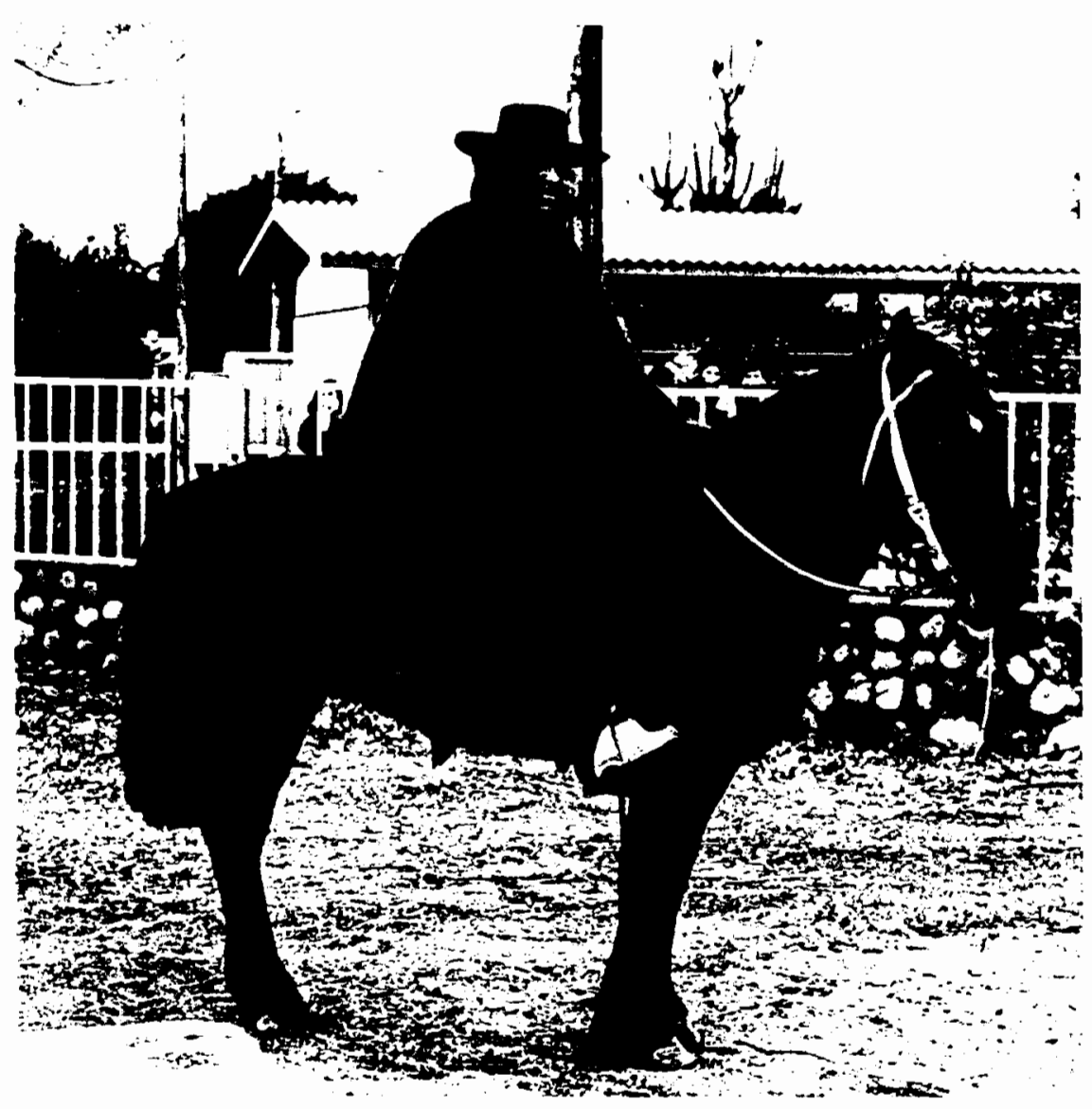

Foto No. 7: Un santabarbarino, Sr. Alfonso Moraga, luciendo una manta de Castilla. 


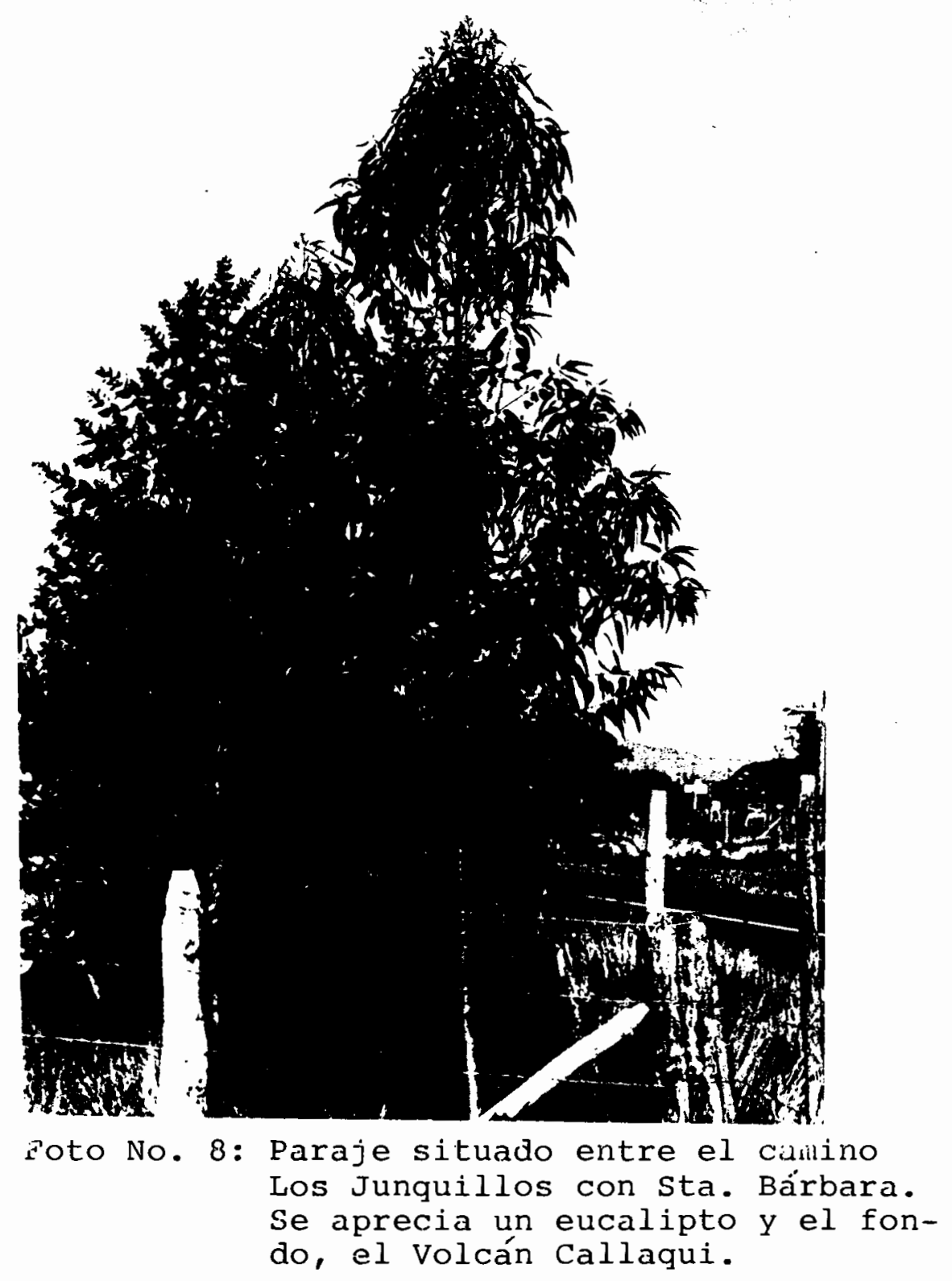


2. Ilustraciones costumbristas varias.
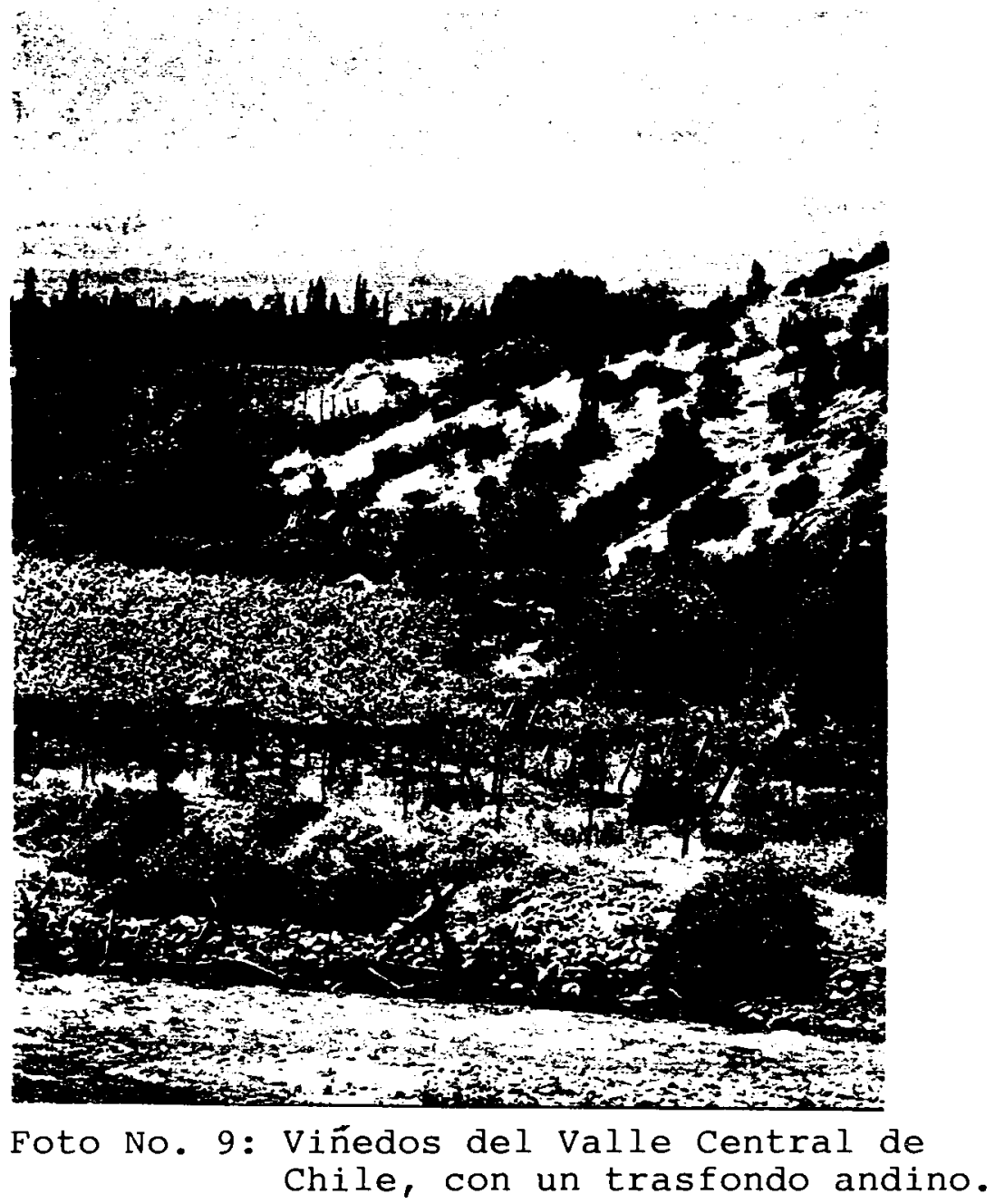


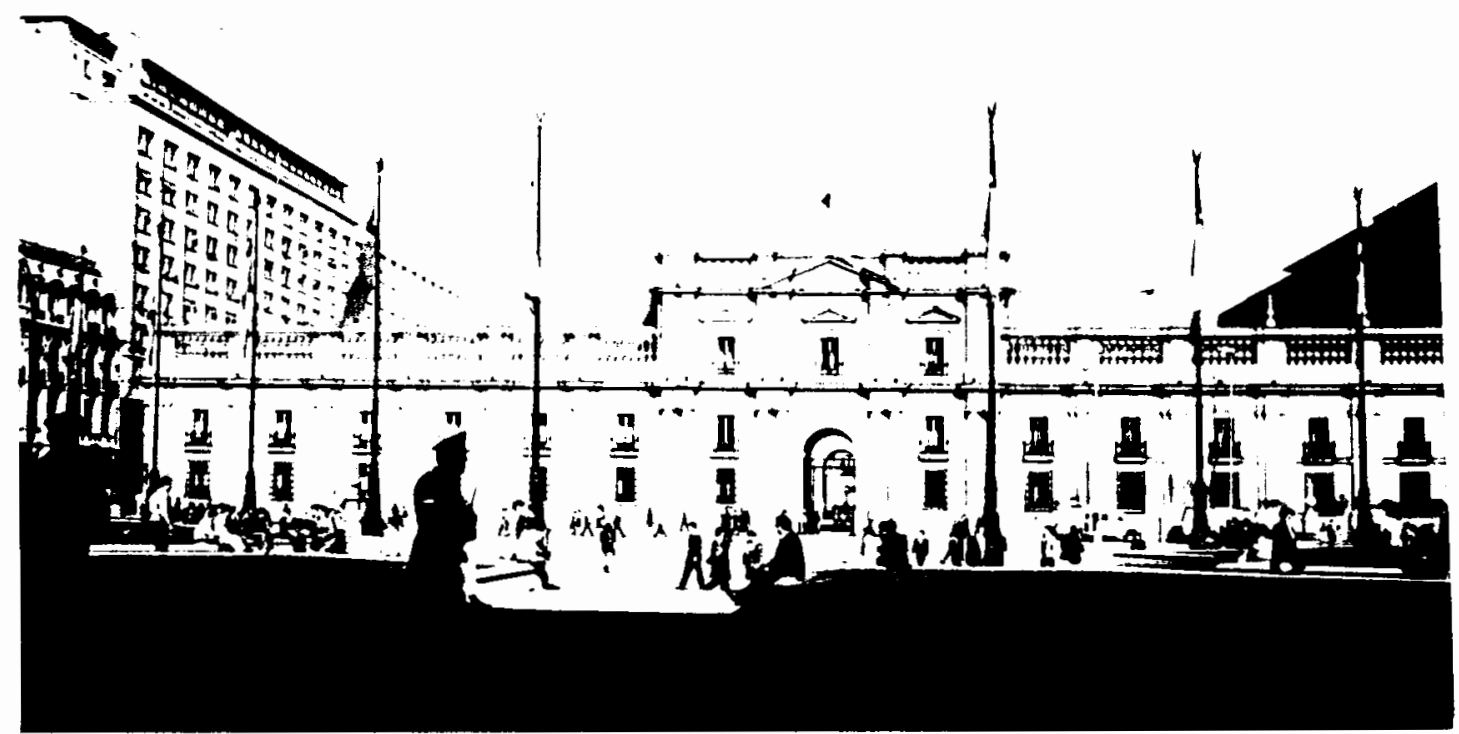

FOTO No. 10: Fachada del Palacio de Chile, La Moneda, waibardeado aurante el golpe de estado, encabezado por A. Pinochet, en donde perdiera la vida el Dr. Salvador Allende Gossens.

(Fotos Nos. 10-13 son gentileza de Nelson e Ingrid Lagos).

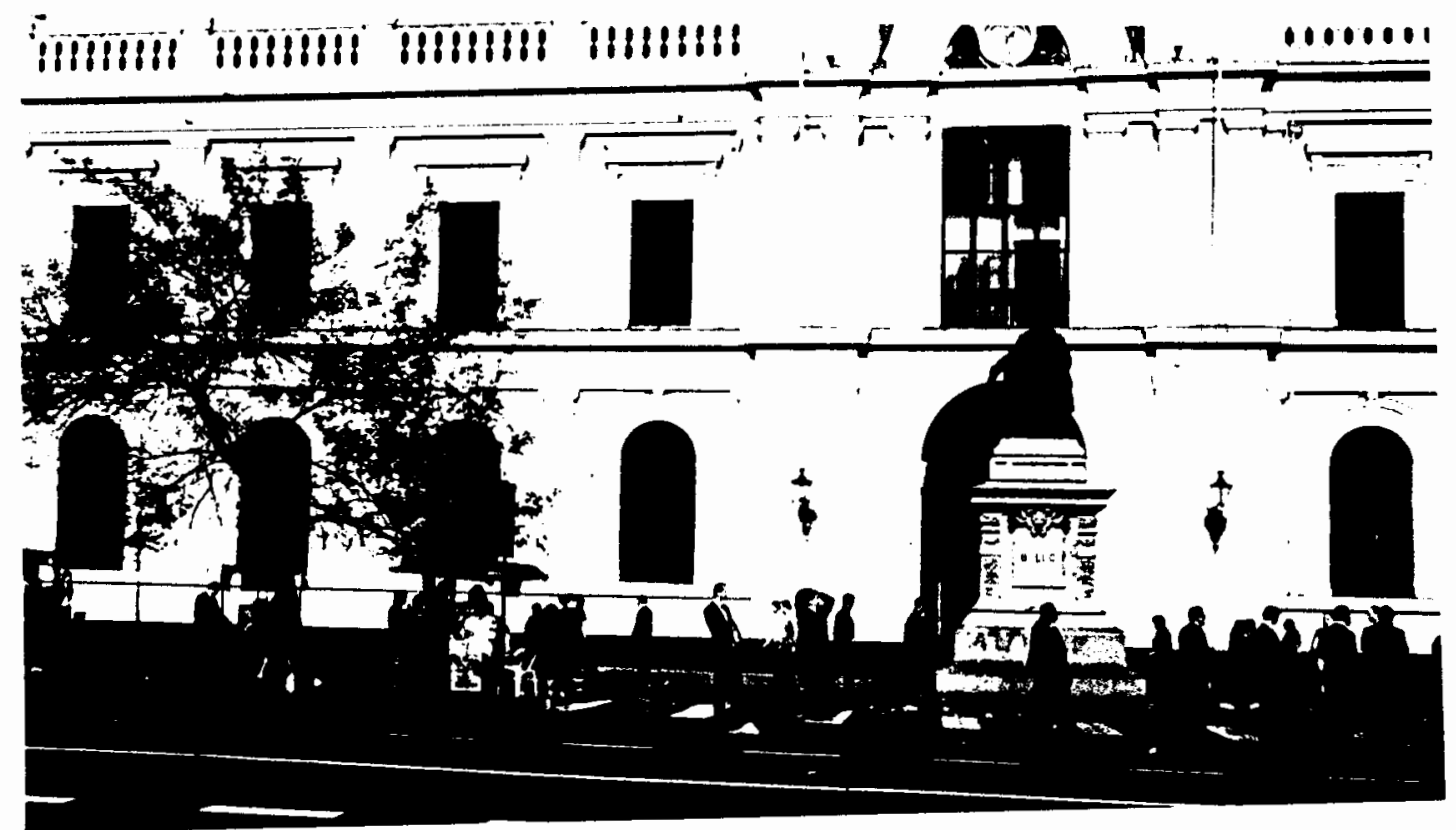

Fulu No. 11: Frontis de la Universida de Chile, cuya estatua de su fundador le vigila. 


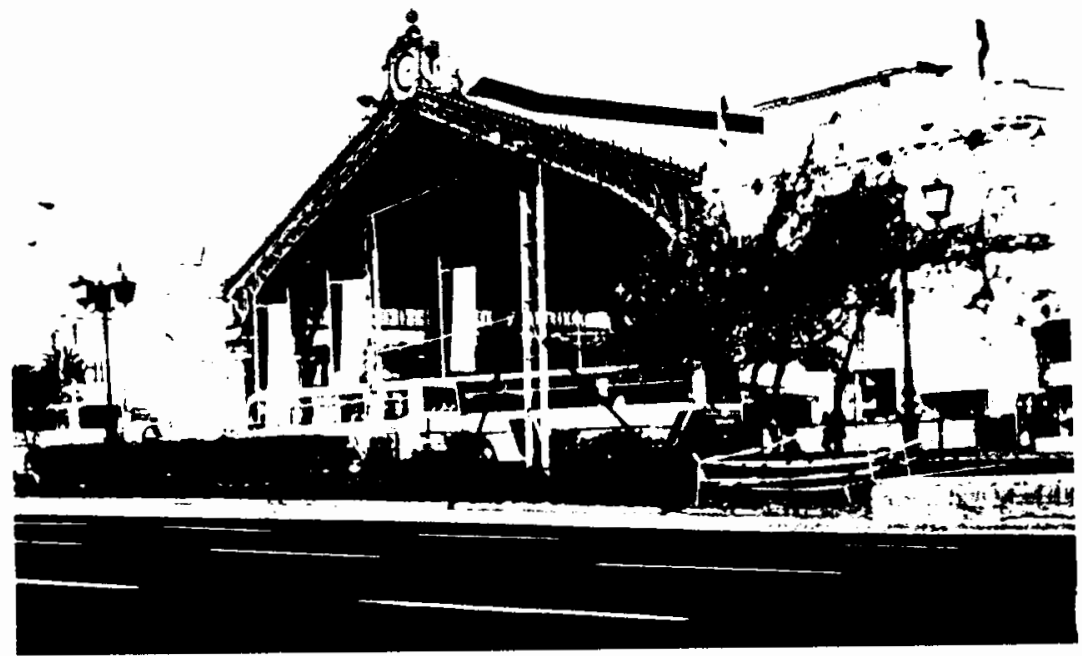

OTO No. 12: Fachada de la Estación Central con su cúpula metálica, construida en 1897. Se encuentra en el Gran Santiago, en la Avda. Libertador Bernardo O'Higgins.

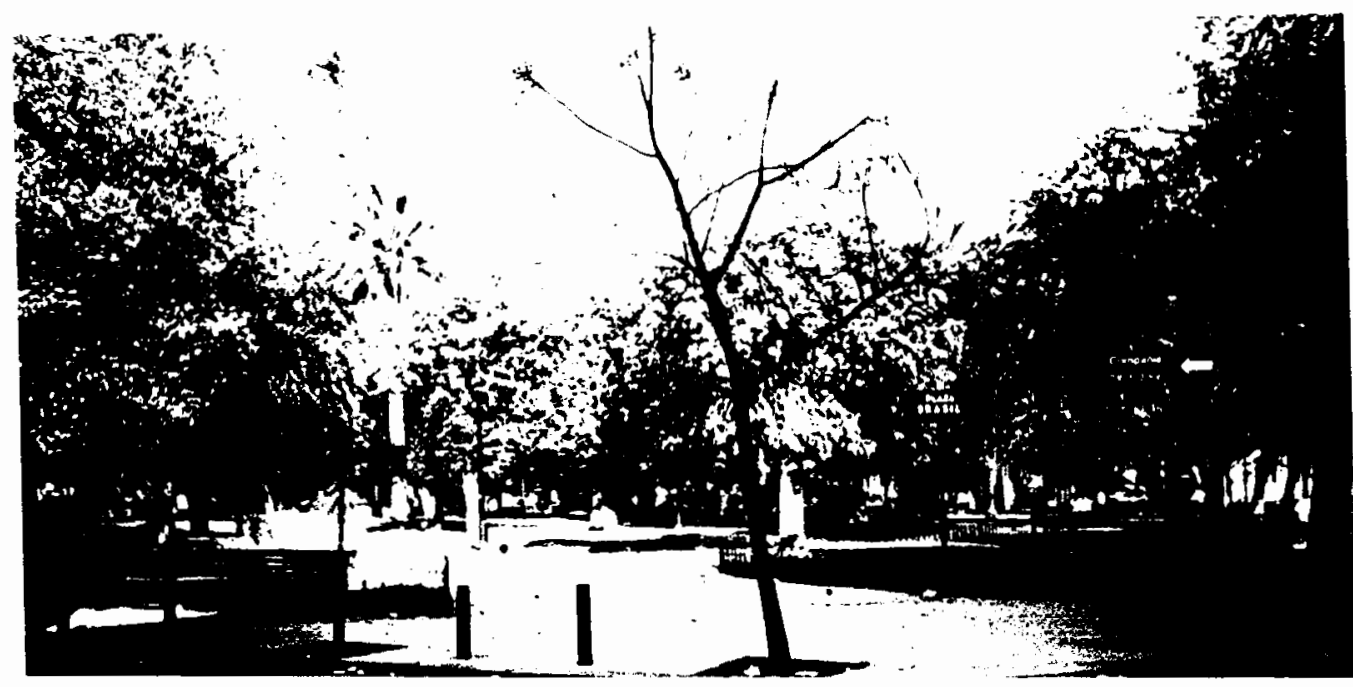

FOTO No. 13: Plaza Brasil, en el centro de Santiago. 


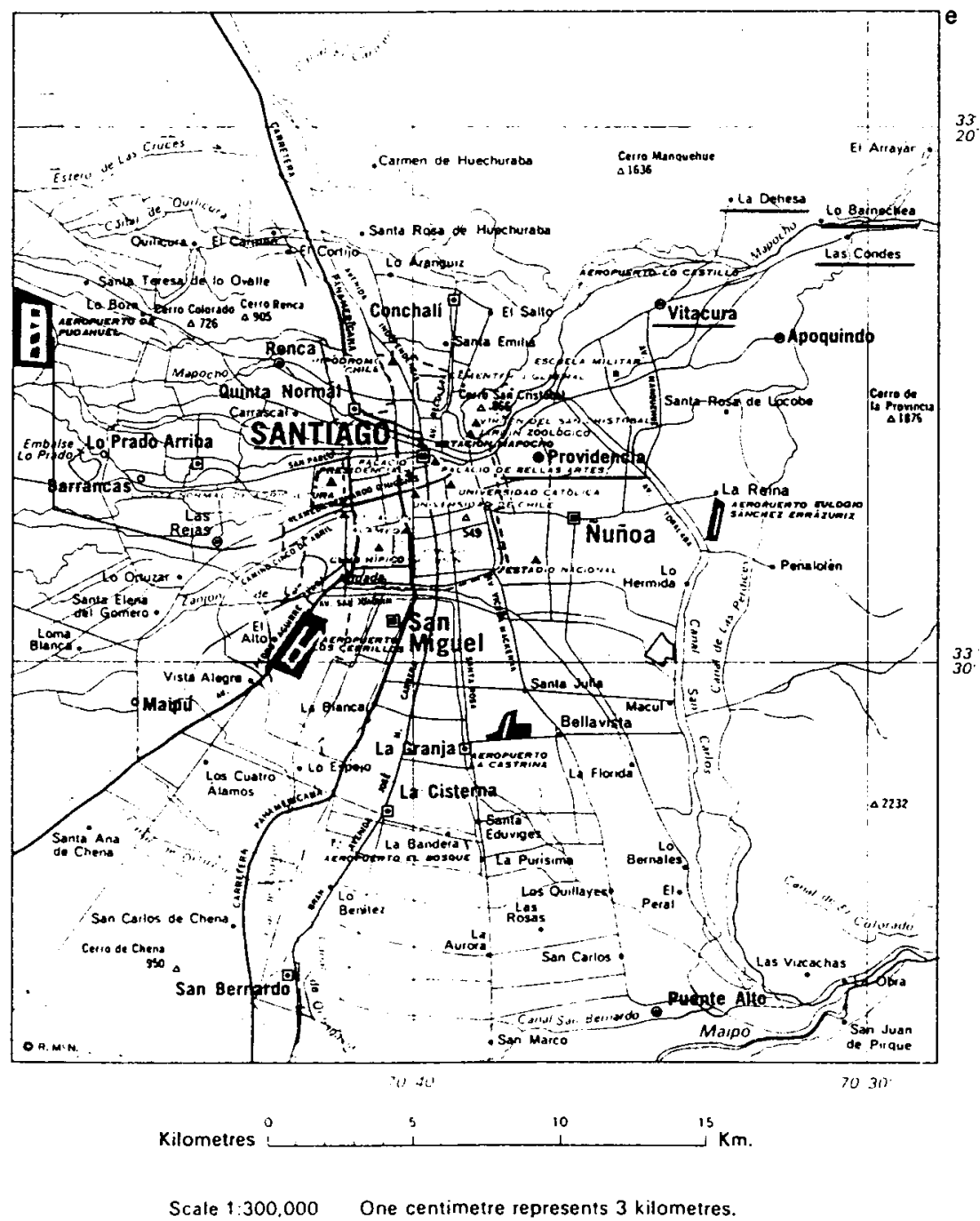

FOTO No. 11: Mapa de Santiago. Nótese que desde el Gran Santiago, el Barrio Alto se extiende al Oriente. (Mapa McRàleq-, gentileza de Embajadora de Chile en Australia, Sra. Rosita Serrano). 


\section{NOTAS EXPLICATIVAS}

\footnotetext{
i A expensas del conejo, muchos en Chile disfrutan de su caza por los campos precordilleranos.

ii La caza de la perdiz es también popular en los campos chilenos y las diferentes cocciones que ésta permite. (La especie nativa de perdiz en Chile, recibe el nombre de "perdiz cojón").

iii Como el tubérculo originario de la Isla de Chiloé cuya variedad se expandió rápidamente por Europa y otros continentes (similar al caso de la Fuchsia magellanica).

iv Casi la totalidad de estos manjares se puede preparar siguiendo las recetas de Luisa Becker et al. Gran libro de la cocina chilena. (Santiago: Editorial Bibliográfica Chilena, 1993).

` El terremoto de Chillán (situado a aprox. 2 horas de este Fundo) en 1939, dejó un saldo de 30.000 muertos. Además, más al sur, en Valdivia en 1960, hubo un terremoto, causando 5.000 muertes y un drástico cambio en el relieve de ciudades y lagos cercanos. (Torechio 171)
} 